\title{
Mineralogical and chemical composition of Ediacaran-Cambrian pelitic rocks of The Tamengo and Guaicurus formations, (Corumbá Group - MS, Brazil): Stratigraphic positioning and paleoenvironmental interpretations
}

\author{
Gabriella Fazio $^{a}$, , Edi Mendes Guimarães ${ }^{\mathrm{a}, * *}$, Detlef W.G. Walde ${ }^{\mathrm{a}}$, Dermeval A. do Carmo ${ }^{\mathrm{a}}$, \\ Rodrigo R. Adorno $^{\mathrm{a}, \mathrm{b}}$, Lucieth Cruz Vieira ${ }^{\mathrm{a}}$, Matheus Denezine ${ }^{\mathrm{a}}$, Carolina Blois da Silva ${ }^{\mathrm{a}}$, \\ Hygor Viana de Godoy ${ }^{a}$, Patrícia Caixeta Borges ${ }^{\mathrm{a}}$, David Pinho ${ }^{\mathrm{c}}$ \\ a Instituto de Geociências, Universidade de Brasília, Campus Darcy Ribeiro, Ala Central, Brasília, DF, 70910-900, Brazil \\ ${ }^{\mathrm{b}}$ Geological Survey of Brazil, Serviço Geológico Brasileiro, DIPALE-CPRM, Av. Brasil, 1731, Belo Horizonte, MG, 30140-003, Brazil \\ ${ }^{\mathrm{c}}$ Departamento de Geologia, Universidade Federal do Mato Grosso, Av. Fernando Correa da Costa, 2.367, Cuiabá, MT, 78.060-900, Brazil
}

\section{A R T I C L E I N F O}

\section{Keywords:}

Corumbá

Petrography

Tamengo

Guaicurus

$\mathrm{XRD}$

$\mathrm{XRF}$

\begin{abstract}
A B S T R A C T
The Tamengo and Guaicurus formations, upper units of the Corumbá Group, are placed at Ediacaran-Cambrian transition due to biostratigraphy and chemostratigraphy data. The Tamengo Formation is composed mainly of limestones with interbedded mudrocks (siliciclastic, carbonate and mixed siliciclastic-carbonate mudrocks) and record occurrences of macro-fossils Cloudina and Corumbella. The Guaicurus Formation is characterized as an extensive and homogeneous siliciclastic siltstone package. This paper focus in sedimentary, petrographic, mineral (XRD) and chemical (XRF) characterizations of mudrocks and siltstones in order to define stratigraphic positioning of the Tamengo and Guaicurus formations, and indicate depositional environment. To this purpose, three areas were studied in the vicinity of Corumbá (MS-Brazil): Laginha and Corcal quarries and an outcrop along MS-243 road. The rocks of the Tamengo Formation, under microscope, present fluid diffusion features as well as irregular laminations, calcite laminas as evaporate pseudomorphes and biogenic mats. In contrast, siltstones of the Guaicurus Formation are persistently laminated, well sorted and homogenous. Both mudrocks interbedded in carbonate layers and siltstones are composed of detrital quartz, mica and diagenetic clay minerals. Furthermore, the major oxides compositions are broadly similar, except for $\mathrm{Na}_{2} \mathrm{O}$, higher in the Guaicurus Formation. The presence of carbonate rocks and mudrocks within the Tamengo Formation imply environment favorable to carbonate formation with episodically immature siliciclastic supply, from very fine-grained rocks of a nearby area, interrupting carbonate depositions. The Guaicurus Formation, distinctively, is a result of an uninterrupted immature siliciclastic supply from a nearby source area, broadly similar to the Tamengo Formation, and was deposited under a low energy setting in a high water level, below fair-weather wave. Petrographic features and diagenetic clay mineral paragenesis - illite + chlorite + smectite - within the Tamengo Formation indicate fluid circulation event. This event resulted in a complex diagenetic history with a possible retrograde diagenesis recorded in the mudrocks of the Tamengo Formation. The siltstones of the Guaicurus Formation present neither petrographic evidences of fluid diffusion nor presence of smectite along the paragenesis illite + chlorite, constraining the event in the Tamengo Formation. After these characterizations, the research revealed that the superior portion of Corcal quarry (L7) exposes rocks from the Tamengo Formation.
\end{abstract}

\section{Introduction}

The Neoproterozoic Era recorded several changes in paleogeographic configurations related to the breakup of supercontinent Rodinia and posterior amalgamation of Gondwanaland (Li et al., 2003). This Era also registered paleoenvironment changes, such as glaciations as suggested by the Snowball Earth hypothesis (Hoffman et al., 1998) which is possible to carry strict relation to deposition of cap carbonate sequences, characterized by very negative $\delta^{13} \mathrm{C}$ signature (Och and Shields-Zhou, 2012). Moreover, extensive volcanism is recorded in

\footnotetext{
* Corresponding author.

** Corresponding author.

E-mail addresses: faziogabriella@gmail.com (G. Fazio), rxedi@unb.br (E.M. Guimarães).
} 
possible association with rifting processes of Rodinia breakup (Gernon et al., 2016; Lyu et al., 2017), which could have resulted into a large emission of gases and, thus, changes within atmosphere and ocean chemistries.

In the Precambrian-Cambrian transition, it is possible to see an increase in the amount of oxygen (Fike et al., 2006; Och and ShieldsZhou, 2012) that implies modifications in oxygen and carbon cycles. According to Kennedy et al. (2006), a shift from mechanical to chemical weathering and, consequently, variation in clay minerals in shales, are related to an increase in organic matter burial, favoring $\mathrm{O}_{2}$ accumulation in the atmosphere. These events lead to biological innovations (Walde et al., 2015) which are widely studied for biostratigraphic markers, such as Ediacara-type macrofossils - Cloudina and Corumbella -, acanthomorphs, bilaterian trace fossil, among others (Xiao et al., 2016).

In Brazil, these events are recorded in the Paraguay Belt, a late PanAfrican-Brasiliano age fold belt, specifically in the Corumbá Group. The fossil assemblage found in the upper units of the Corumbá Group - the Tamengo and Guaicurus formations - places it in the Ediacaran Cambrian transition (Zaine and Fairchild, 1987; Gaucher et al., 2003; Boggiani and Alvarenga, 2004; Parry et al., 2017). Other than paleontological data, supplementary evidences assign these formations to this important geological time. C and Sr isotopic curves show similarities to other late Ediacaran units in Uruguay, Namibia, South China and Oman (Boggiani et al., 2010). Additionally, zircons from volcanic ashes in the superior portion of the Tamengo Formation were dated at $543 \pm 3$ Ma by U-Pb method (Babinski et al., 2008) which was, later on, supported by Parry et al. (2017), who dated ash beds from the same location at around 542Ma by $\mathrm{U}-\mathrm{Pb}$ method.

Extensive bibliography has been produced regarding the Corumbá Group and its Ediacaran paleontological record (Beurlen and Sommer, 1957; Fairchild, 1978; Hahn et al., 1982; Walde et al. 1982, 2015; Zaine and Fairchild, 1985; Zaine, 1991; Hidalgo, 2002; Gaucher et al., 2003; Kerber et al., 2013; Tobias, 2014; Adorno et al., 2017; Parry et al., 2017) and focusing on stratigraphy and structural features (Barbosa, 1949; Almeida, 1964, 1965, 1984; Alvarenga and Trompette, 1992; Boggiani and Alvarenga, 2004; Gaucher et al., 2003; Babinski et al., 2008; Boggiani et al., 2010; Meira, 2011; Spangenberg et al., 2014; D'elRey et al., 2016; Sial et al., 2016) and on sedimentation context (Boggiani et al., 1993; Boggiani, 1998; Oliveira, 2010; Campanha et al., 2011; Fontanela, 2012).

Nevertheless, despite these references, few studies are focused on mineral composition. Oliveira (2010) states the clay mineral paragenesis of mixed-layer clay mineral illite/smectite + illite + kaolinite in the mudrock facies of the Tamengo Formation. Walde et al. (2015) briefly described the mineralogy of the mudrocks of the Tamengo Formation, using XRD analysis, as composed of quartz, muscovite, smectite and chlorite, whereas their clay fractions are composed mainly of smectite, illite, quartz and chlorite. Guimarães et al. (2013), Guimarães et al. (2014) and Fazio et al. (2016), all of them are abstracts in congresses, present the clay minerals paragenesis of illite + smectite + chlorite in the mudrocks of the Tamengo Formation. Fazio et al. (2016) state briefly that the mineral composition of the Tamengo and Guaicurus formations differ on clay mineralogy proxies.

Chemical and mineral compositions of the siliciclastic rocks facilitate paleogeography interpretation and diagenetic evolution. This research focuses on the discussion of stratigraphic relations between the Tamengo and Guaicurus formations and their depositional context by characterizing the pelitic rocks in the vicinity of Corumbá (MS).

\section{Geology}

The lithostratigraphy of the Corumbá Group was first defined by Almeida (1965), with posterior contribution by Boggiani (1998), and it comprises five formations: Cadieus, Cerradinho, Bocaina, Tamengo and Guaicurus (Fig. 1A).
The basal clastic sequence of the Corumbá Group consists in conglomerates, arkoses and shales, from the Cadieus and Cerradinho formations (Fig. 1A; Boggiani and Alvarenga, 2004; Gaucher et al., 2003). These units are covered by stromatolitic dolomites with phosphorites of the Bocaina Formation (Boggiani, 1998), which are related to shallow, warm water environment with high evaporation conditions (Sial et al., 2016; Fontanela, 2012; Oliveira, 2010). The upper portion of the Corumbá Group is composed by the Tamengo and Guaicurus formations (Fig. 1A; Almeida, 1965).

The Tamengo Formation presents, from base to top, breccias, diamictites and dolomites followed by thick dark gray limestones with interbedded mudrocks (Boggiani, 1998). These limestones bear an Ediacaran index fossil, Cloudina lucianoi (Beurlen and Sommer, 1957), while Corumbella werneri (Hahn et al., 1982) occur in the mudrocks (Almeida, 1965, 1984; Zaine, 1991; Boggiani, 1998; Gaucher et al., 2003; Boggiani et al., 2010; Guimarães et al., 2014). According to Boggiani (1998) this stacking represents a turbiditic sedimentation with low sea level and reworked slope, followed by a progressive water level increase until deposition in a higher water level at the top. Oliveira (2010), however, interprets the Tamengo Formation within two facies associations, (1) shoreface with oolitic bars, with deposition of mudrock facies between these bars, protected from the current, and (2) storminfluenced offshore. According to this author, the first one presents oolitic limestones and microbial mats, indicating deposition in high energy settings, with influence of currents or waves, whereas the presence of hummocky and swaley in limestones indicates influence of storm waves in offshore associations.

The Guaicurus Formation consists of thick homogenous gray siltstone package and, according to Boggiani (1998), Gaucher et al. (2003) and Oliveira (2010), is probably deposited bellow fair-weather wave base related to an abrupt climate change or a drowning of the basin.

These upper formations are the focus of the present paper. Their contact is controversial at different localities in Corumbá region and surroundings. At Laginha quarry, the contact is abrupt, according to Adorno et al. (2017). At Corcal quarry, Boggiani et al. (2010) consider this contact as well exposed. At Bodoquena Ridge, it is gradual with increase of quantity and thickness of interbedding mudstones (Campanha et al., 2011).

The Corumbá region is, according to Jones (1985) and (Walde, 1988; in Walde et al., 2015), placed above a triple junction, the convergence point of three basins, south and north Paraguay and Tucavaca aulacogen, the latter with an WNW trend into Bolivia (Fig. 1B and 1. C; delgado et al., 2003; Freitas, 2010; Walde et al., 2015). Extensional tectonics, just before the Ediacaran Period, generated a graben system, the Corumbá graben, parallel to the southern border of the Amazon craton (Boggiani, 1998; Trompette et al., 1998; Walde et al., 2015). This graben is delimited by high angle normal faults with an NE-SW dominant direction (Jones, 1985) and was first filled by the Jacadigo Group and the Puga Formation and, later on, by the Corumbá Group (Walde et al., 2015). The rift stage of the Corumbá graben is presented by the Cadieus and Cerradinho formations, whereas the post-rift to drift stages are associated to the Bocaina, Tamengo and Guaicurus formations (Boggiani et al., 2010).

The NW-SE Brasiliano deformation affected these rocks in greenschist metamorphism with gradual increase to the interior of the Paraguay fold belt (Alvarenga and Trompette, 1992; D'el-Rey et al., 2016). This metamorphism is indirectly dated at $504 \pm 24 \mathrm{Ma}$ e $504 \pm 12 \mathrm{Ma}$ on São Vicente Granite, intruded in the fold belt, with $\mathrm{Rb} / \mathrm{Sr}$ and K/Ar methods, respectively (Almeida and Mantovani, 1975 in Trompette et al., 1998).

\section{Materials and methods}

In order to characterize the superior units of the Corumbá Group the Tamengo and Guaicurus formations - and their contact, three areas were selected: Corcal and Laginha quarries, in the Corumbá region, and 


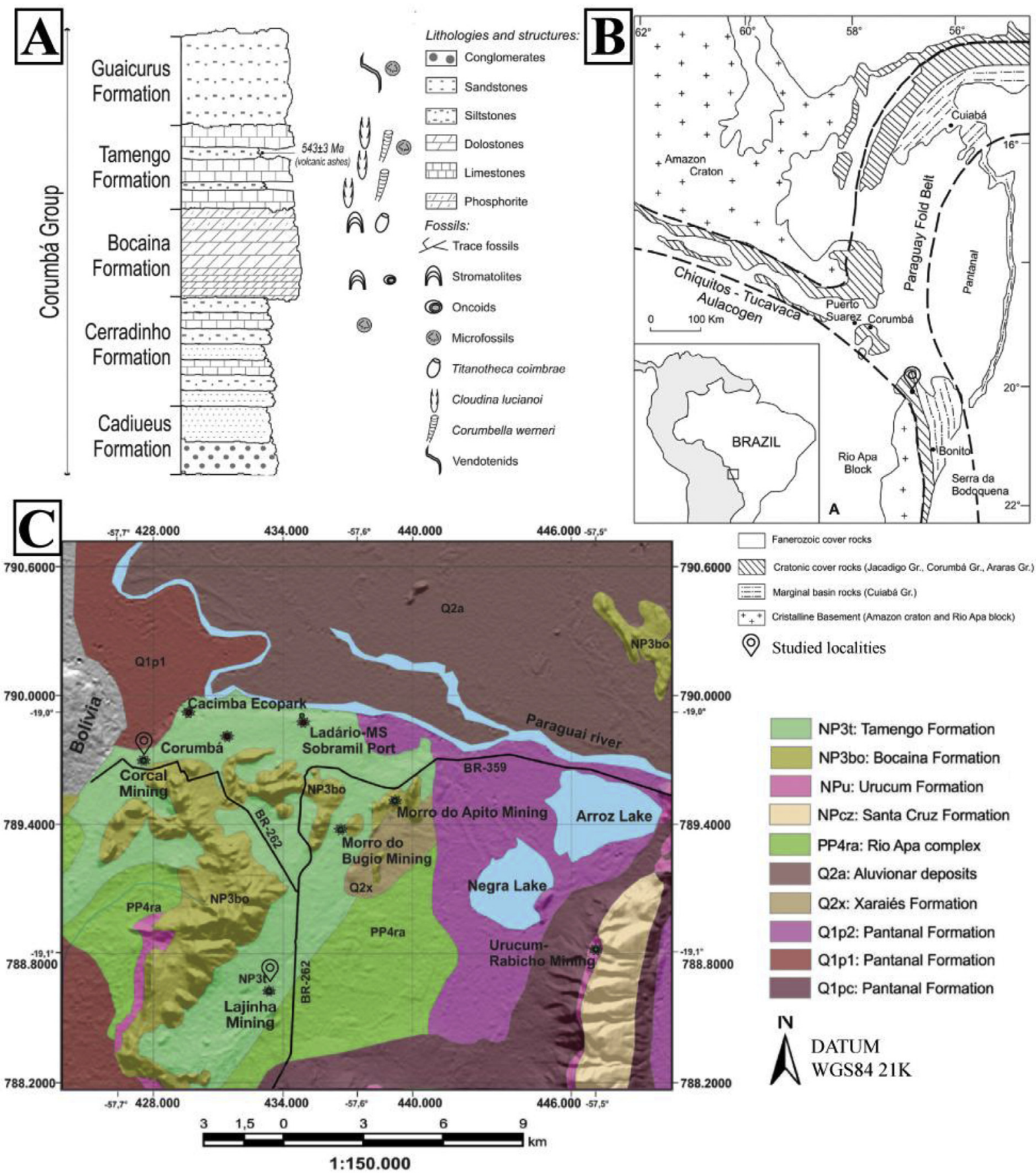

Fig. 1. A. Lithostratigraphic column of the Corumbá Group with fossil content and dated zircons from volcanic ashes by Boggiani et al. (2010) (modified from Walde et al. (2015)). B. Map of the Brasiliano Paraguay fold belt and the Chiquitos-Tucavaca Aulacogen including the outcrop along MS-243 (pointed), near Guaicurus Station and Corumbá city (modified after Walde et al. (2015)). C. Regional geological map pointing Laginha and Corcal quarries and Corumbá and Ladário cities (modified from Walde et al. (2015) and Adorno et al. (2017)).

Table 1

Minerals abbreviations according to Whitney and Evans (2010).

\begin{tabular}{llllll}
\hline Albite & $\mathrm{Ab}$ & Smectite & Sme & Muscovite & Ms \\
\hline Calcite & Cal & Gypsum & Gp & Quartz & Qz \\
Clorite & Chl & Goethite & Gth & Rectorite & Rec \\
Corrensite & Crr & Illite & Ill & Vermiculite & Vrm \\
Dolomite & Dol & Kaolinite & Kln & & \\
\hline
\end{tabular}

outcrop along MS-243 road, close to Guaicurus Station, which is type locality of the Guaicurus Formation. The last two localities are accessed by following BR-262 road in about $15 \mathrm{~km}$ and $150 \mathrm{~km}$ from Corumbá city, respectively (Fig. 1B and 1C).

This paper presents stratigraphic stacking from both quarries as well as petrographic, mineralogical and geochemical aspects from the three localities. The paper focus on the mudrocks of the Tamengo Formation, these being siliciclastic, carbonate and mixed siliciclastic-carbonate rocks, and also on the siliciclastic siltstones of the Guaicurus Formation. The mineral compositions were determined by X-Ray Diffraction (XRD), textures and structures of the mudrocks were studied through 

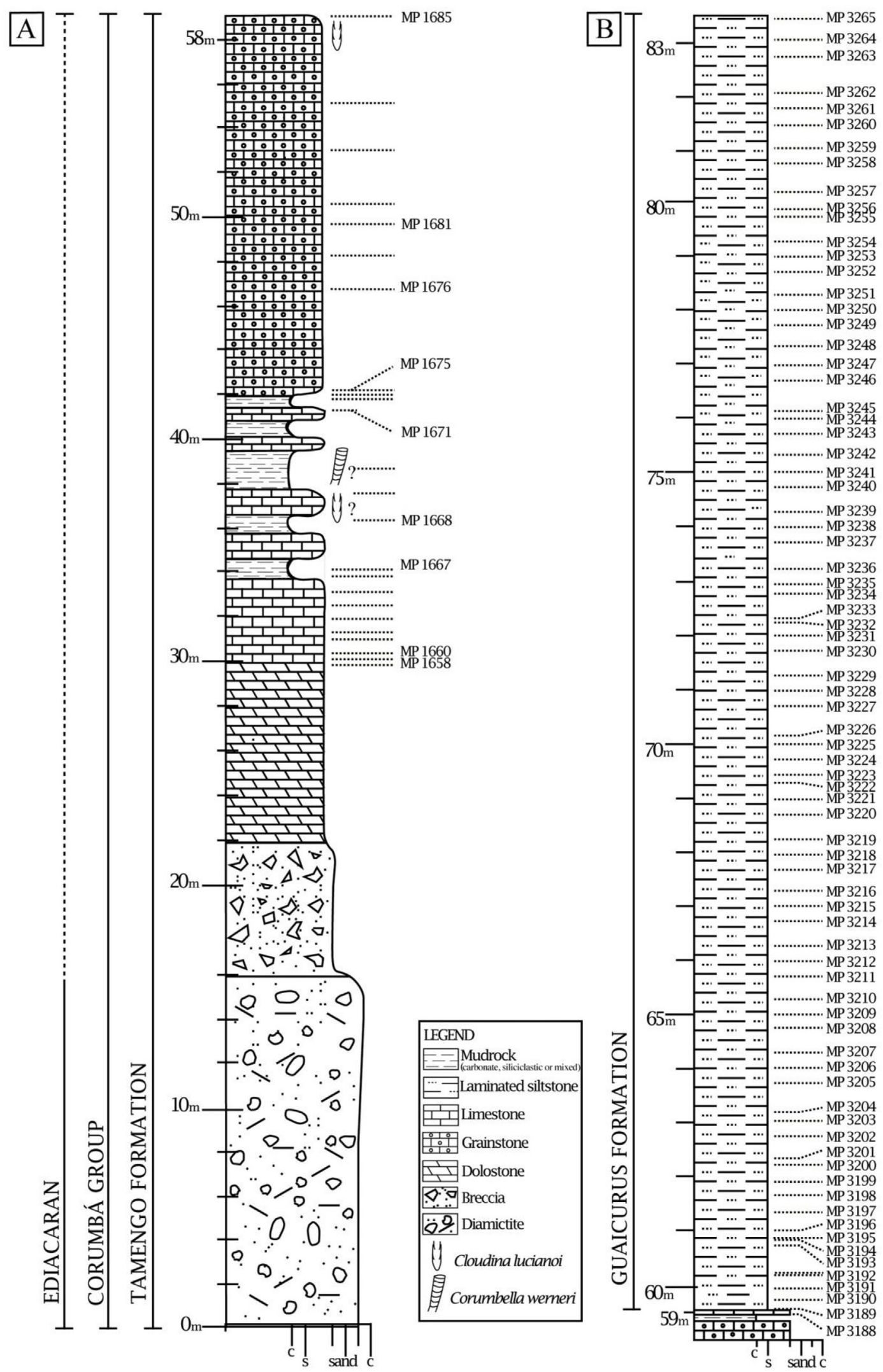

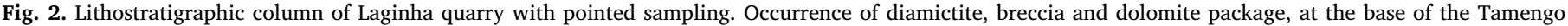

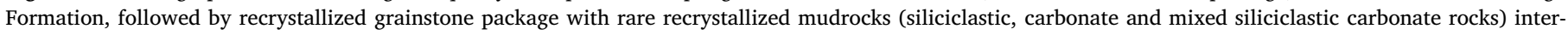
bedding. On top of it, we observe siliciclastic siltstones of the Guaicurus Formation with $24 \mathrm{~m}$ of detail sampling. 

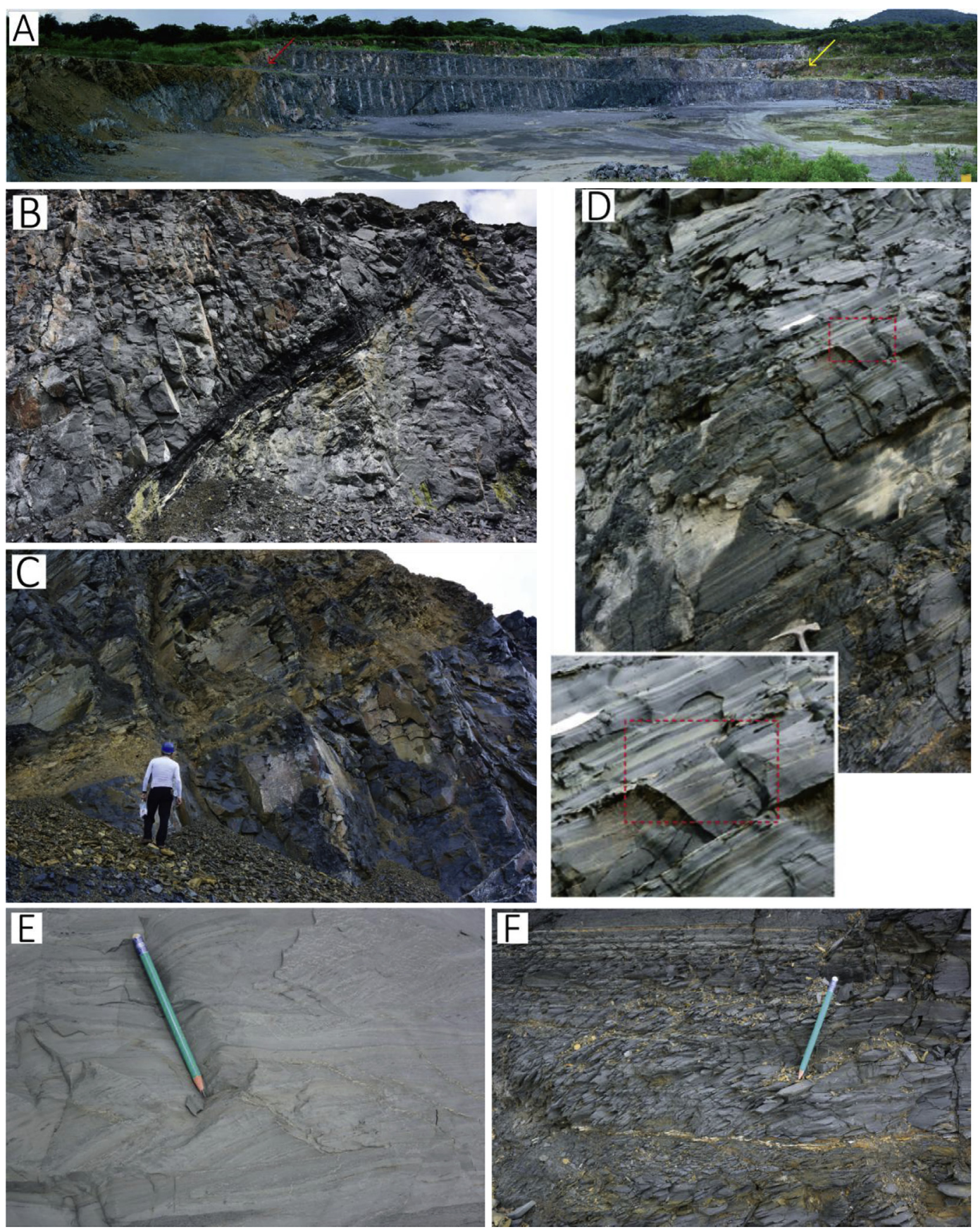

Fig. 3. Photographs of features and structures from Laginha quarry.

A: Panoramic view of Laginha quarry. Yellow arrow points to the base of the Tamengo Formation, while the red arrow points to the contact between the Tamengo and Guaicurus formations (level $59 \mathrm{~m}$ of the column).

B: Detail of mudrock layer compressed and deformed between limestones layers and occurrence of sub vertical fractures in the Tamengo Formation.

D: Laminated siliciclastic siltstones of the Guaicurus Formation with spaced cleavages oblique to lamination. The red rectangle highlights load ynsedimentar structure.

C: Contact between the Tamengo (below) and Guaicurus (above) formations, which could have facilitate fluid circulation.

E: Synsedimentar structure, slump, in siliciclastic siltstones of the Guaicurus Formation.

F: Penetrative cleavages in siliciclastic siltstones of the Guaicurus Formation.

petrography and the chemical compositions were determined by X-Ray Fluorescence (XRF).

Minerals, within this article, are identified in tables and figures with abbreviations proposed by Whitney and Evans (2010; Table 1).

\subsection{Stratigraphy}

This paper brings the stratigraphic columns of Laginha and Corcal quarries with an additional detailed description of their superior portions, than the ones found in Boggiani et al. (2010) and Adorno et al. (2017). Both upper portions of the quarries were sampled every $30 \mathrm{~cm}$, reaching a total of $84 \mathrm{~m}$ for the Laginha quarry and $68 \mathrm{~m}$ for the Corcal quarry, 24 and $29 \mathrm{~m}$ more than the columns previously presented. 


\subsection{Petrography}

Due to their silt and clay grain size, petrography studies of the mudrocks were focused in describing textures and structures. Several thin sections from the Tamengo Formation previously described by Guimarães et al. (2014) were analyzed. Mudrock thin sections from the superior portions of the quarries were prepared. All of them were made at Geoscience Institute/Universidade de Brasília (IG/UNB) and studied under a ZEISS petrographic microscope in X-Ray Diffraction Laboratory (LARIX).

The carbonate identification was performed with $\mathrm{HCl}(0.2 \%)$ and stains of potassium ferricyanide $(0.5 \%)$ e alizarin $(0.2 \%)$ in petrographic thin sections. The carbonate classification followed Dunham (1962) and Flügel (2004) classifications.

\section{3. $X$-ray diffraction}

Sample preparation initially included material disaggregation with a hammer and powdering in the Planetary Mill pulverisette by Fritsch, for $5 \mathrm{~min}$ with $400 \mathrm{rpm}$. X-ray powder diffraction was performed on whole rock samples, as well as on clay fractions. Clay fractions $(<2$ $\mu \mathrm{m})$ were separated by centrifugation routine at LARIX described in Campos (2012), modified from Alves (1987).

The measurements were undertaken in whole rock $(W)$ and oriented clay fractions in air-dried (AD) conditions, after ethylene-glycol (EG) saturation, after glycerol (GL) saturation and after heating $(\mathrm{H})$ for $4 \mathrm{~h} 30 \mathrm{~min}$ at $490{ }^{\circ} \mathrm{C}$. Analyses were performed in a RIGAKU Ultima IV diffractometer equipped with $\mathrm{CuKa}$ radiation, Ni filter, under $35 \mathrm{kV}$ and $15 \mathrm{~mA}$. The samples were scanned at $5^{\circ} / \mathrm{min}$ velocity, 0,05 stepping ranging from 2 to $80^{\circ} 2 \theta$ for whole rock and from 2 to $40^{\circ} 2 \theta$ for clay fraction. Mineral phases were identified using Jade XRD 9.0 (Materials Data) with PC-PDF (Powder Diffraction File - PDF for PC - ICDD).

Major (M), minor (m) and trace (tr) components were established by comparing the reflection intensities in d: $4.26 \AA$ for quartz, $7 \AA$ for kaolinite, $10 \AA$ for illite and $14 \AA$ for chlorite or smectite, when expansive after ethylene-glycol saturation.

\subsection{X-ray fluorescence}

XRF analyses were performed at Regional Center to Technological Development and Innovation of Universidade Federal de Goiás (CRTI/ UFG) and at Universidade de Brasília. Some samples were analyzed at both these laboratories in order to observe positive compatibility for future interpretations.

The analyses performed at CRTI/UFG used WDS Bruker S8 Tiger spectrometer with Rh tube, and calibrated by Bruker GeoQuan M package. The mudrocks with minimal carbonate contribution were initially dried at $105^{\circ} \mathrm{C}$ for $12 \mathrm{~h}$. For major oxide analyses, samples were heated at $1000^{\circ} \mathrm{C}$ for $5 \mathrm{~h}$ in order to determine the loss on ignition (LOI). Afterwards, a portion of $1 \mathrm{~g}$ of the sample was fused with $9 \mathrm{~g}$ of lithium tetraborate. XRF analyses were also performed at Universidade de Brasília in pressed powder pellets using Rigaku ZSX Primus II spectrometer.

\section{Pelitic rocks of Laginha and Corcal quarries and outcrop along Ms-243}

The present research established stratigraphic and petrographic characterization besides mineral and chemical compositions of the mudrocks of the three chosen localities.

\subsection{Stratigraphy}

The most complete exposure of the Tamengo Formation in the Corumbá region is at the Laginha quarry, overlaid by the Guaicurus Formation (Boggiani, 1998; Boggiani et al., 2010, Figs. 2 and 3A).
The Tamengo Formation, at Laginha quarry, is composed at its base by $20 \mathrm{~m}$ thick diamictites and breccias and an $8 \mathrm{~m}$ dolomite layers. On top of it, $30 \mathrm{~m}$ of dark recrystallized limestone occur, including rhythmite facies interpreted as shoreface association (Oliveira, 2010), presenting rare dark recrystallized laminated mudrocks, these being siliciclastic, carbonate and mixed siliciclastic-carbonate rocks. Layers bearing Cloudina are found at beds of recrystallized grainstones at the base and top of this package, along with storm wave structures. This package dips $20-30^{\circ}$ SE (Fig. 3B) and presents sub-vertical calcite or quartz-filled fractures. Emphasis is given to the lack of continuality of these fractures in the overlying siliciclastic siltstone beds.

The contact between the superior grainstone of the Tamengo Formation and the superposed siliciclastic siltstone is well outlined, abrupt and presents millimetric irregularities (Fig. 3C).

The first meter of the siliciclastic siltstone package (at $59 \mathrm{~m}-60 \mathrm{~m}$ in Fig. 2) presents non-cohesive yellowish beige siltstones followed by a $23 \mathrm{~m}$ package of bluish gray siltstone with persistent laminations (Fig. 2B and 3D). These parallel laminations are defined by alternation of lighter and darker bluish gray silt lamina (Fig. 3D). Synsedimentary deformation structures occur, such as slumps (Fig. 3E) and, rarely, load structures (Fig. 3D). These layers also dip 20-30 ${ }^{\circ} \mathrm{SE}$ (Fig. 3C), similar to the underneath rocks, granting a concordant characteristic to the stacking. Spaced cleavages are frequent along the column and locally appear penetrative (Fig. 3D and 3F).

At the Corcal quarry, where the base layers of the Tamengo Formation are not exposed - diamictites and dolomites - Adorno et al. (2017) demark the stratigraphic column as a stacking of six layers - L1 to L6 - corresponding the inferior and medium portion of the quarry, lifting up to $40 \mathrm{~m}$ (Fig. 4A, 5A and 5B). L1, L3 and L5 layers are recrystallized mudrocks in which these two last bear Corumbella, with eventual interbedded recrystallized grainstones formed by bioclasts of Cloudina. Oliveira (2010) describes these recrystallized mudrocks, siliciclastic, carbonate and mixed siliciclastic-carbonate rocks, as an offshore association. The other three (L2, L4 and L6) are recrystallized limestones, which most of them bear Cloudina bioclasts.

The superior portion of this quarry (described posteriorly to Adorno et al., 2017) is mainly composed by mudrocks, these being siliciclastic, carbonate and mixed siliciclastic-carbonate rocks, assigned to the Guaicurus Formation by Boggiani et al. 2010; Fig. 4B, 5C and 5E.

In the present paper, this superior portion is identified as L7, a $28 \mathrm{~m}$ package which was studied in detail. This package is mainly yellowish beige (Fig. 5D and 5E) with important carbonate contribution (calcite and, rarely dolomite) being classified as mixed siliciclastic-carbonate rocks, and, occasionally, can be individualized as limestones levels along the column. These mudrocks are characterized for its laminations parallel to bedding, defined by an alternation of lighter and darker yellowish beige laminas.

The Corcal quarry presents folds, faults and calcite or quartz-filled fractures, as well as spaced cleavages oblique to bedding, which dips around $20-30^{\circ} \mathrm{NW}$. According to D'el-Rey et al. (2016), despite its overall deformation, stratigraphic positions along the layers are preserved.

The siltstones of the outcrop along MS-243 are yellowish beige to gray and present persistent laminations (Fig. 6A). These parallel laminations are defined by alternation of lighter and darker gray to beige laminas (Fig. 6B). These rocks show bed dipping around $60^{\circ}$.

\subsection{Petrography}

In petrography analysis, several carbonatic and siliciclastic samples were observed belonging to the Tamengo Formation from the Corcal and the Laginha quarries. These samples were also compared with other localities such as Cacimba Ecopark (Guimarães et al., 2014, Fig. 1C).

Among the Tamengo Formation samples, it was possible to classify carbonate, siliciclastic and mixed siliciclastic-carbonate rocks, but due to an intensive recrystallization, the recognition of the original 



Fig. 4. Lithostratigraphic column of Corcal quarry with pointed sampling. The column presents interbedding of limestones and mudrocks (siliciclastic, carbonate and mixed siliciclastic-carbonate rocks) of Tamengo Formation (layers L1 to L6) and a package composed mainly of mudrocks (also siliciclastic, carbonate and mixed siliciclastic-carbonate) previously assigned to Guaicurus Formation (layer L7). 

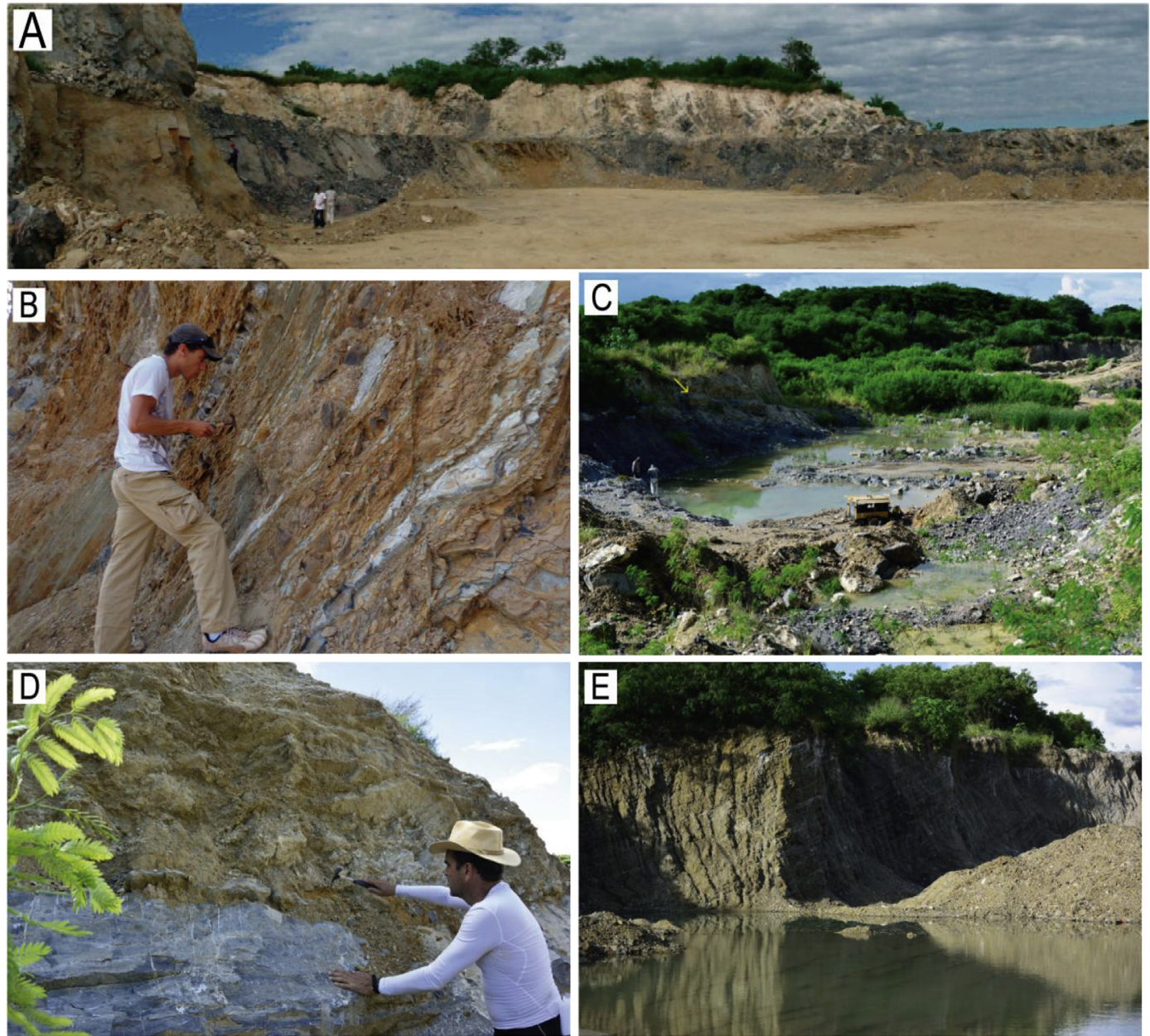

Fig. 5. Photographs of features and structures from Corcal quarry.

A- Panoramic view of Corcal quarry, L1 to L6 layers.

B - Within the mudrock layer of Tamengo Formation we observe centimetric to milimetric carbonate laminas.

C - Panoramic view of the superior portion of Corcal quarry. Yellow arrow points the contact between layers L6 and L7.

D - Contact between layers L6 (carbonate) and L7 (mudrocks).

E - Layer L7 with lamination shown by incipient change in the color of the rocks.
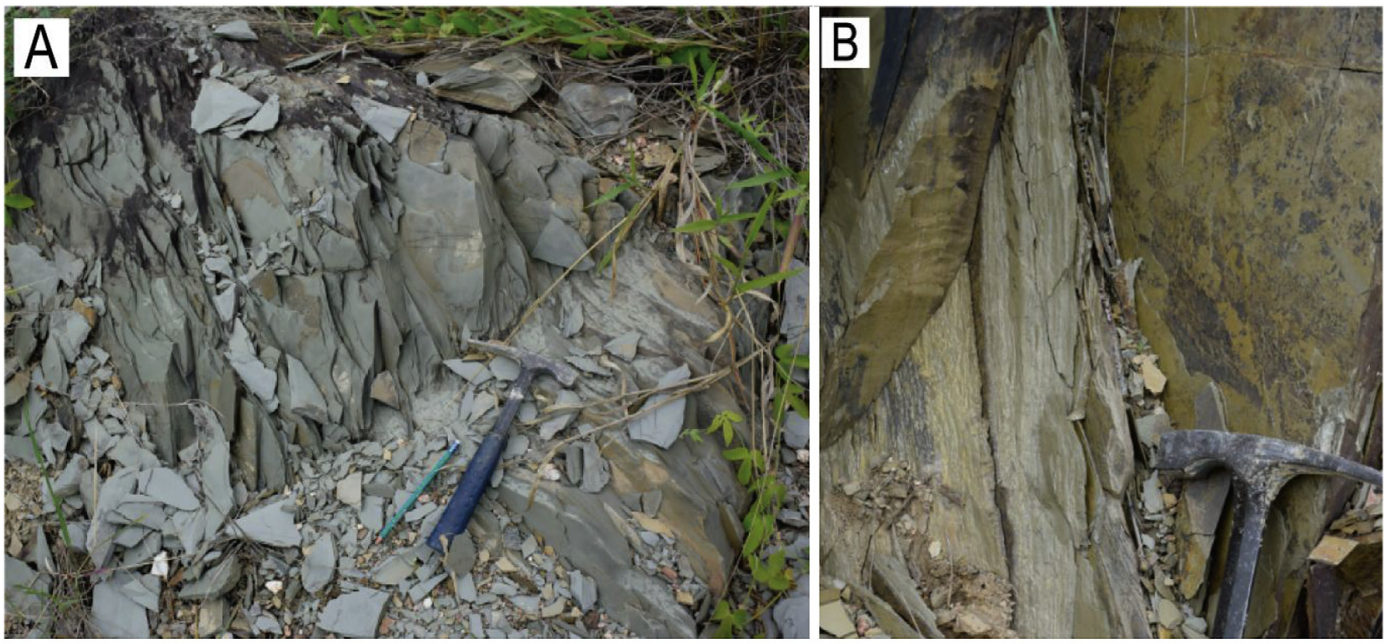

Fig. 6. A. Intensively laminated siltstones at outcrop along MS-243. B. Detail of laminations parallel to bedding, defined by alternation of silt and clay slides. 

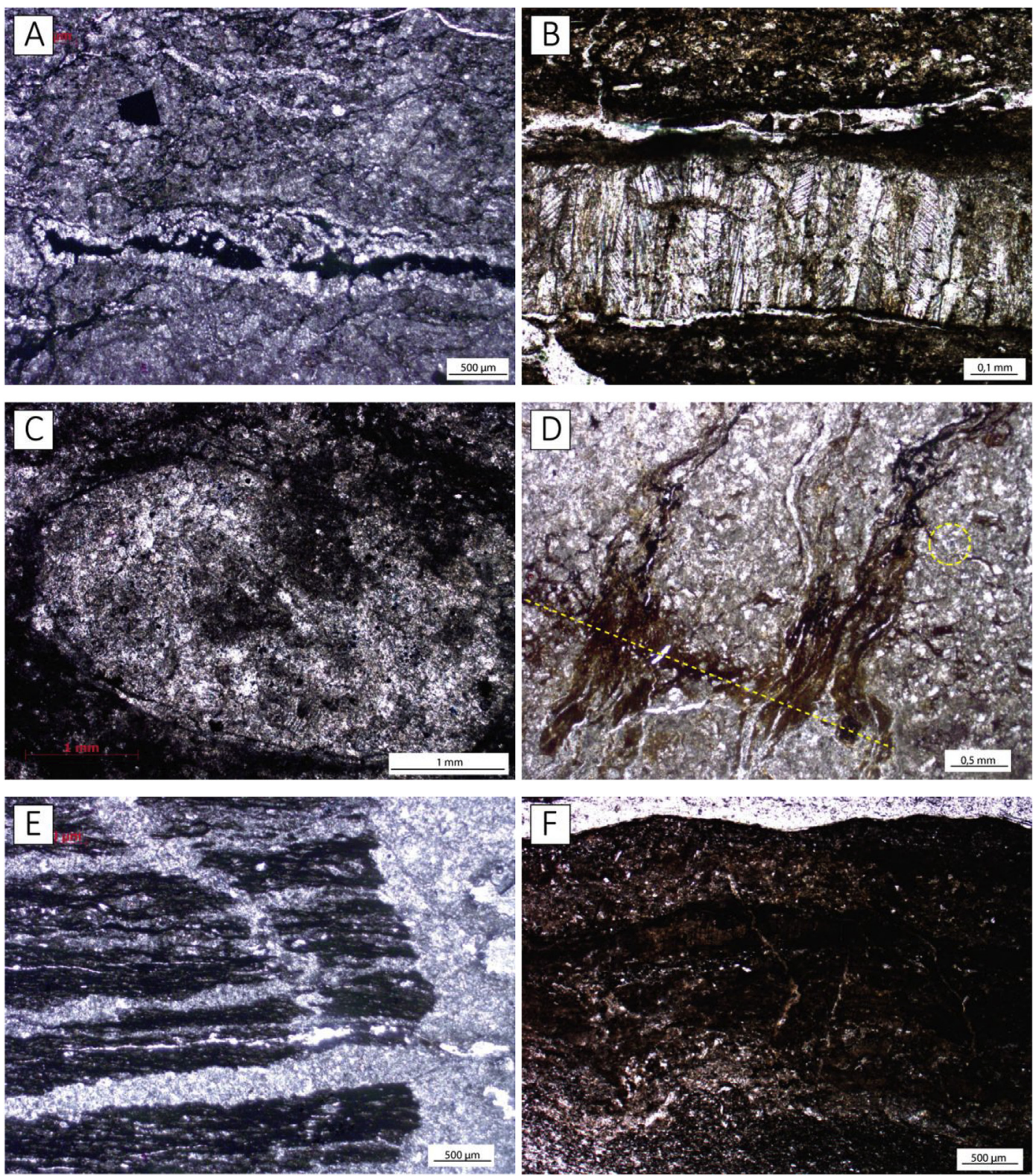

Fig. 7. Photomicrography of carbonate rocks and mudrocks (carbonate, siliciclastic and mixed siliciclastic-carbonate), belonging to Tamengo Formation. ARecrystallized limestone presenting millimetric druse filled with opaque material, interpreted as organic matter. Above it, there is sub-euhedral pyrite crystal. N//. MP1664. Laginha quarry. B- Carbonate mudrock with thin fibrous gypsum-filled laminae. NX. MP1592. Cacimba Ecopark. C- Microfossil, in limestone, presenting substitution by calcite. N//. MP1619. Corcal quarry. D- Recrystallized limestone with fluid diffusion features of tortuously network non concordant to lamination (marked) composed by calcite microveins and opaque material associated to calcite or dolomite crystals dissolution or substitution (yellow arrow). N//. MP1617. Corcal quarry. E- Irregular laminated mixed siliciclastic-carbonate mudrock, classified as argillaceous limestone, with alternation of lighter to darker color and presenting calcite-filled fractures with fluid diffusion features. N//. MP1658. Laginha quarry. F- Biogenic mat interbedded in microbial argillaceous limestone. N//. MP1593. Cacimba Ecopark. (For interpretation of the references to color in this figure legend, the reader is referred to the Web version of this article.)

petrographic features has been hampered. Besides the lack of preserved original features, there are millimetric to centimetric lateral microfacies variations that difficult the characterization within the stratigraphic column.

In carbonate petrography, we can, tentatively, indicate the presence of packstones, wackestones and grainstones, with eventual contributions of gypsum and dolomite. Preserved depositional features are bioclasts like Cloudina, ooids and incipient lamination. Early diagenetic features are concretions and sub-euhedral pyrite crystal (Fig. 7A), visible also macroscopically. Late diagenetic events changed evaporate crystals in prismatic calcite pseudomorphes, perpendicular to lamination (Fig. 7B) and also provoked limestones recrystallization, with total to partial bioclasts and ooids substitution to calcite (Fig. 7C). Diagenetic calcite is often poikilotropic or mosaic.

Locally, these carbonate rocks present stylolites concordant, or not, to lamination and calcite or quartz-filled fractures. Among the highlight aspects, there are fluid diffusion features (Fig. 7D), which are indicated by a tortuously network, non-concordant to lamination, with calcite microveins and opaque material, possibly organic matter. This feature is often associated to calcite or dolomite crystal dissolution or substitution (Fig. 7D). Fluid diffusion features are also seen as millimetric calcite druse filled with organic matter (Fig. 7A).

The mixed siliciclastic-carbonate mudrocks are argillaceous limestones and also microbial argillaceous limestones (according to Flügel, 2004). These are characterized by an irregular and discontinous alternation of microspatic laminae and quartz-rich mudrock or siltstone 

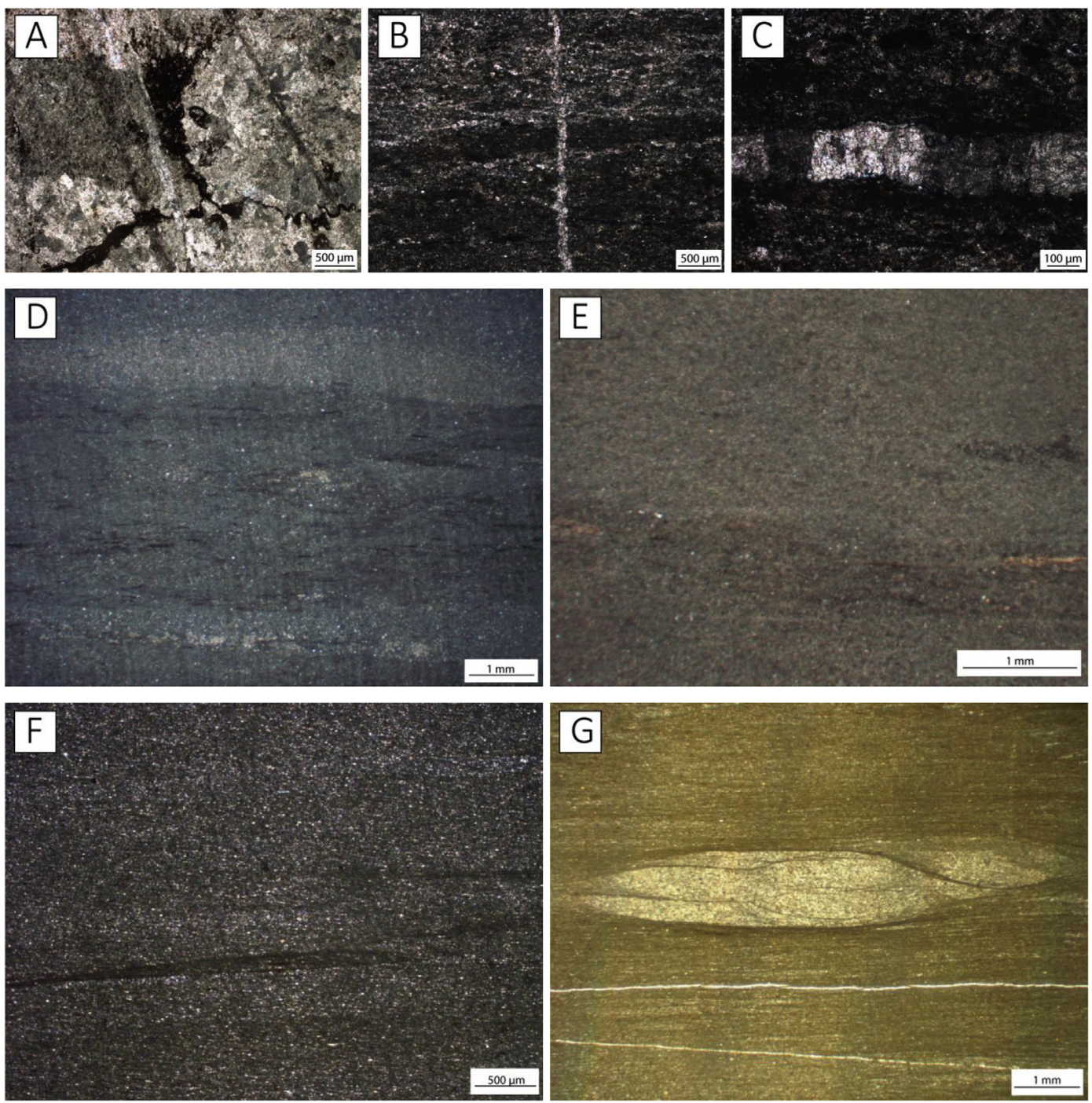

Fig. 8. Photomicrography of the superior portions of Corcal and Laginha quarries and of the outcrop along MS-243. A- Limestone with fluid diffusion features composed by opaque material and with stylolites. NX. MP3155. Corcal quarry. B- Mixed silicilastic-carbonate mudrock, classified as argillaceous limestone, with calcite-filled fracture perpendicular to lamination with fluid diffusion features. NX. MP3141. Corcal quarry. C- Detail of prismatic calcite-filled laminae as gypsum pseudomorph, in argillaceous limestone. NX. MP3141. Corcal quarry. D- Laminated siltstone defined by oriented lamellar minerals interbedded with granular lamina and opaque material films. NX. MP3212. Laginha quarry. E- Detail of oriented lamellar minerals parallel to bedding, in laminated siltstone. N//. MP3227. Laginha quarry. Detail of opaque material discontinuous films parallel to bedding, in laminated siltstone. NX. MP3809. Outcrop along MS-243. G- Laminated siltstone with sub-parallel fractures and with very fine sand lens with flux deposition indicator. N//. GG1. Outcrop along MS-243.

laminae with calcite contribution. Often these rocks present gypsumfilled laminae or calcite-filled laminae as gypsum pseudomorph. Bioclasts with total to partial substitution is frequent as well as fluid diffusion features associated to calcite or quartz-filled fractures (Fig. 7E), which are perpendicular to sub perpendicular to lamination. The microbial argillaceous limestones present dome or planar biogenic mat (Fig. 7F).

It's possible to observe siltstones to claystones as siliciclastic rocks within the Tamengo Formation. These are characterized by an irregular and discontinous alternation of siliciclastic material and opaque films. They also present fractures perpendicular to sub perpendicular to lamination, often filled by calcite and with fluid diffusion features associated.

Thin sections of the rocks from the superior portion of Corcal quarry (L7) - mudrocks (carbonate, siliciclastic and mixed siliciclastic-carbonate) and limestones - are also intensive recrystallized, hampering the recognition of the original petrographic, and present similar aspects to the ones described for the inferior and medium portion of Corcal quarry. These are fluid diffusion features in limestone (Fig. 8A) and in fractured mudrock (Fig. 8B), as well as prismatic calcite-filled laminae as gypsum pseudomorph (Fig. 8C).

Siltstone thin sections of the superior portion of Laginha quarry and of the outcrop along MS-243 show contrasting textures when compared to the previously described mudrocks. The siltstones are well sorted, uniform and planar laminated, defined by oriented lamellar minerals interbedded with granular lamina and opaque material films (Fig. 8D, $8 \mathrm{E}$ and $8 \mathrm{~F}$ ). Occasionally lens of very fine sand occur parallel to bedding, with flux deposition indicators (Fig. 8G), and sub-horizontal quartz or calcite-filled fractures are described locally (Fig. 8G). These siltstones are composed mainly by phyllosilicates, colorless mica/illite, rare scattered biotites and chlorites associated with microlens. Additionally, quartz is a minor component.

\subsection{Mineral compostion (XRD)}

The mudrocks interbedded in carbonate layers, from the Tamengo Formation, in both Laginha and Corcal quarries and other locations (Guimarães et al. 2013, 2014), show, in whole rock analyses, essentially 
Table 2

Mineral composition of samples collected at the superior portions of Corcal and Laginha quarries and at outcrop along MS-243, defined with XRD.

\begin{tabular}{|c|c|c|c|c|c|c|c|c|c|c|}
\hline \multicolumn{11}{|c|}{ CORCAL QUARRY } \\
\hline SAMPLE & LEVEL & Sme & Chl & Ill & $\mathrm{Qz}$ & Cal & $\mathrm{Ab}$ & Gth & Others & Lithotype \\
\hline MP3183 W & $68,7 \mathrm{~m}$ & M & $\mathrm{m}$ & $\mathrm{m}$ & M & & & $\operatorname{tr}$ & & Mudrock \\
\hline$<2 \mu \mathrm{m}$ & & M & M & M & $\mathrm{m}$ & & & $\operatorname{tr}$ & Crr:tr & \\
\hline MP3181 W & $68 \mathrm{~m}$ & M & $\mathrm{m}$ & $\mathrm{m}$ & M & & & $\operatorname{tr}$ & & Mudrock \\
\hline$<2 \mu \mathrm{m}$ & & M & M & M & $\mathrm{m}$ & & & $\operatorname{tr}$ & Crr:tr & \\
\hline MP3179 W & $67,7 \mathrm{~m}$ & M & $\mathrm{m}$ & $\mathrm{m}$ & M & & & $\operatorname{tr}$ & & Mudrock \\
\hline$<2 \mu \mathrm{m}$ & & M & M & M & $\mathrm{m}$ & & & $\operatorname{tr}$ & Crr:tr & \\
\hline MP3177 W & $67,1 \mathrm{~m}$ & M & $\mathrm{m}$ & $\mathrm{m}$ & $\mathrm{M}$ & & & $\operatorname{tr}$ & & Mudrock \\
\hline$<2 \mu \mathrm{m}$ & & M & M & M & $\mathrm{m}$ & & & $\operatorname{tr}$ & Crr:tr & \\
\hline MP3175 W & $66,4 \mathrm{~m}$ & M & $\mathrm{m}$ & $\mathrm{m}$ & $\mathrm{M}$ & M & & $\operatorname{tr}$ & & Calcite mudrock \\
\hline$<2 \mu \mathrm{m}$ & & M & M & M & $\mathrm{m}$ & $\operatorname{tr}$ & & $\operatorname{tr}$ & Crr:tr & \\
\hline MP3174 W & $65,6 \mathrm{~m}$ & M & $\mathrm{m}$ & $\operatorname{tr}$ & $\mathrm{M}$ & M & & $\operatorname{tr}$ & Dol:M & Calcite mudrock \\
\hline$<2 \mu \mathrm{m}$ & & M & M & M & $\mathrm{m}$ & $\mathrm{m}$ & & $\operatorname{tr}$ & Dol:tr; Crr:tr & \\
\hline MP3172 W & $65 \mathrm{~m}$ & M & $\mathrm{m}$ & $\mathrm{m}$ & $\mathrm{M}$ & & & $\operatorname{tr}$ & Dol:tr & Mudrock \\
\hline$<2 \mu \mathrm{m}$ & & M & M & M & $\mathrm{m}$ & & & $\operatorname{tr}$ & Dol:tr & \\
\hline MP3170 W & $64,4 \mathrm{~m}$ & M & $\mathrm{m}$ & $\operatorname{tr}$ & $\mathrm{M}$ & & & $\operatorname{tr}$ & Dol:M & Dolomite mudrock \\
\hline$<2 \mu \mathrm{m}$ & & M & M & M & M & & & $\operatorname{tr}$ & Dol:M & \\
\hline MP3168 W & $63,6 \mathrm{~m}$ & $\mathrm{~m}$ & $\mathrm{~m}$ & $\mathrm{~m}$ & M & & & $\operatorname{tr}$ & & Mudrock \\
\hline$<2 \mu \mathrm{m}$ & & M & M & M & $\mathrm{m}$ & & & $\operatorname{tr}$ & Crr:tr & \\
\hline MP3167 W & $63,3 \mathrm{~m}$ & M & M & M & $\mathrm{m}$ & & & $\operatorname{tr}$ & & Mudrock \\
\hline$<2 \mu \mathrm{m}$ & & M & M & M & $\mathrm{m}$ & & & $\operatorname{tr}$ & Crr:tr & \\
\hline MP3165 W & $62,7 \mathrm{~m}$ & M & $\mathrm{m}$ & $\mathrm{m}$ & $\mathrm{M}$ & & & $\operatorname{tr}$ & & Mudrock \\
\hline$<2 \mu \mathrm{m}$ & & M & M & M & $\mathrm{m}$ & & & $\operatorname{tr}$ & Crr:tr & \\
\hline MP3163 W & $61,7 \mathrm{~m}$ & M & $\mathrm{m}$ & $\mathrm{m}$ & $\mathrm{M}$ & & & $\operatorname{tr}$ & Rec:tr & Mudrock \\
\hline$<2 \mu \mathrm{m}$ & & M & M & $\mathrm{m}$ & $\mathrm{m}$ & & & $\operatorname{tr}$ & Rec:tr & \\
\hline MP3161 W & $61,1 \mathrm{~m}$ & M & $\mathrm{m}$ & $\mathrm{m}$ & M & & & $\operatorname{tr}$ & Rec:tr & Mudrock \\
\hline$<2 \mu \mathrm{m}$ & & M & M & $\mathrm{m}$ & $\mathrm{m}$ & & & $\operatorname{tr}$ & Rec:tr & \\
\hline MP3159 W & $60,45 \mathrm{~m}$ & M & $\mathrm{m}$ & $\operatorname{tr}$ & M & & & & Rec:tr & Mudrock \\
\hline$<2 \mu \mathrm{m}$ & & M & M & $\mathrm{m}$ & $\mathrm{m}$ & & & $\operatorname{tr}$ & Rec:tr & \\
\hline MP3157 W & $59,45 \mathrm{~m}$ & M & $\mathrm{m}$ & $\operatorname{tr}$ & $\mathrm{M}$ & & & & Dol:M, Rec:tr & Dolomite mudrock \\
\hline$<2 \mu \mathrm{m}$ & & M & M & $\mathrm{m}$ & $\mathrm{m}$ & & & & Dol:tr, Rec:m & \\
\hline MP3156 W & $59,15 \mathrm{~m}$ & $\mathrm{~m}$ & $\mathrm{~m}$ & $\operatorname{tr}$ & $\mathrm{M}$ & & & $\operatorname{tr}$ & Dol:tr, Rec:m & Mudrock \\
\hline$<2 \mu \mathrm{m}$ & & M & M & $\mathrm{m}$ & $\mathrm{m}$ & & & $\operatorname{tr}$ & Rec:m & \\
\hline MP3155 W & $59 \mathrm{~m}$ & & & & $\operatorname{tr}$ & M & & & Dol:tr & Limestone \\
\hline MP3154 W & $56,1 \mathrm{~m}$ & $\operatorname{tr}$ & $\operatorname{tr}$ & $\operatorname{tr}$ & $\mathrm{m}$ & M & & & Dol:tr & Argillaceous limestone \\
\hline$<2 \mu \mathrm{m}$ & & M & M & $\mathrm{m}$ & $\mathrm{m}$ & M & & $\operatorname{tr}$ & Dol:tr, Rec:m & \\
\hline MP3153 W & $55 \mathrm{~m}$ & $\mathrm{~m}$ & $\operatorname{tr}$ & $\operatorname{tr}$ & $\mathrm{m}$ & M & & & Dol:tr & Calcite mudrock \\
\hline$<2 \mu \mathrm{m}$ & & M & $\mathrm{m}$ & $\mathrm{m}$ & $\mathrm{m}$ & $\mathrm{m}$ & & $\operatorname{tr}$ & Dol:tr, Rec:m & \\
\hline MP3151 W & $53,7 \mathrm{~m}$ & $\mathrm{~m}$ & $\operatorname{tr}$ & $\operatorname{tr}$ & $\mathrm{m}$ & M & & $\operatorname{tr}$ & Dol:tr & Calcite mudrock \\
\hline$<2 \mu \mathrm{m}$ & & M & $\mathrm{m}$ & $\mathrm{m}$ & $\mathrm{m}$ & $\mathrm{m}$ & & $\operatorname{tr}$ & Dol:tr, Rec:m & \\
\hline MP3149 W & $52,2 \mathrm{~m}$ & $\mathrm{~m}$ & $\mathrm{~m}$ & $\operatorname{tr}$ & $\mathrm{m}$ & M & & & Dol:m & Calcite mudrock \\
\hline$<2 \mu \mathrm{m}$ & & M & M & $\operatorname{tr}$ & $\mathrm{m}$ & M & & $\operatorname{tr}$ & Dol:m, Rec:tr & \\
\hline MP3147 W & $51 \mathrm{~m}$ & M & $\mathrm{m}$ & $\operatorname{tr}$ & $\mathrm{M}$ & M & & $\operatorname{tr}$ & & Calcite mudrock \\
\hline$<2 \mu \mathrm{m}$ & & M & M & M & $\mathrm{m}$ & $\operatorname{tr}$ & & $\operatorname{tr}$ & Crr:tr & \\
\hline MP3145 W & $50,2 \mathrm{~m}$ & $\mathrm{~m}$ & $\operatorname{tr}$ & $\operatorname{tr}$ & $\mathrm{m}$ & M & & & & Argillaceous limestone \\
\hline$<2 \mu \mathrm{m}$ & & M & M & M & $\mathrm{m}$ & $\mathrm{m}$ & & $\operatorname{tr}$ & & \\
\hline MP3143 W & $49,1 \mathrm{~m}$ & M & $\mathrm{m}$ & $\operatorname{tr}$ & M & M & & & & Calcite mudrock \\
\hline$<2 \mu \mathrm{m}$ & & M & M & $\mathrm{m}$ & $\mathrm{m}$ & $\operatorname{tr}$ & & & Rec:tr & \\
\hline MP3141 W & $48,4 \mathrm{~m}$ & M & $\mathrm{m}$ & $\operatorname{tr}$ & M & M & & & & Calcite mudrock \\
\hline$<2 \mu \mathrm{m}$ & & M & M & $\mathrm{m}$ & $\mathrm{m}$ & $\operatorname{tr}$ & & & Rec:tr & \\
\hline MP3139 W & $47,8 \mathrm{~m}$ & M & $\operatorname{tr}$ & $\mathrm{m}$ & M & M & & & & Argillaceous limestone \\
\hline$<2 \mu \mathrm{m}$ & & M & M & $\mathrm{m}$ & $\mathrm{m}$ & $\mathrm{m}$ & & & Crr:tr & \\
\hline MP3137 W & $46,9 \mathrm{~m}$ & $\mathrm{~m}$ & $\mathrm{~m}$ & $\operatorname{tr}$ & M & M & & & Dol:m, Rec:tr & Calcite mudrock \\
\hline$<2 \mu \mathrm{m}$ & & M & M & $\mathrm{m}$ & $\mathrm{m}$ & $\operatorname{tr}$ & & & Dol:tr, Rec:m & \\
\hline MP3136 W & $46,6 \mathrm{~m}$ & & & & $\operatorname{tr}$ & M & & & & Limestone \\
\hline MP3135 W & $46,2 \mathrm{~m}$ & $\operatorname{tr}$ & $\operatorname{tr}$ & $\operatorname{tr}$ & $\mathrm{M}$ & M & & $\operatorname{tr}$ & Dol:m, Rec:tr & Argillaceous limestone \\
\hline$<2 \mu \mathrm{m}$ & & M & M & M & $\operatorname{tr}$ & & & $\operatorname{tr}$ & Dol:tr, Rec:m & \\
\hline MP3134 W & $45,8 \mathrm{~m}$ & & & & $\operatorname{tr}$ & M & & & & Limestone \\
\hline MP3133 W & $45,5 \mathrm{~m}$ & $\mathrm{~m}$ & $\operatorname{tr}$ & $\operatorname{tr}$ & M & M & & & Dol:m & Calcite mudrock \\
\hline$<2 \mu \mathrm{m}$ & & M & M & $\mathrm{m}$ & $\mathrm{m}$ & $\operatorname{tr}$ & & & Dol:tr, Rec:tr & \\
\hline MP3132 W & $45,1 \mathrm{~m}$ & $\mathrm{~m}$ & $\mathrm{~m}$ & $\operatorname{tr}$ & M & M & & & Dol:M, Rec:tr & Calcite mudrock \\
\hline$<2 \mu \mathrm{m}$ & & M & M & $\operatorname{tr}$ & $\mathrm{m}$ & $\mathrm{m}$ & & & Dol:m, Rec:m & \\
\hline MP3131 W & $44,8 \mathrm{~m}$ & M & $\mathrm{m}$ & $\operatorname{tr}$ & M & M & & & Dol:m, Rec:tr & Calcite mudrock \\
\hline$<2 \mu \mathrm{m}$ & & M & M & $\mathrm{m}$ & $\mathrm{m}$ & $\operatorname{tr}$ & & & Dol:tr, Rec:tr & \\
\hline MP3129 W & $43,9 \mathrm{~m}$ & M & $\mathrm{m}$ & $\operatorname{tr}$ & M & M & & & Dol:tr, Rec:tr & Calcite mudrock \\
\hline$<2 \mu \mathrm{m}$ & & M & M & $\mathrm{m}$ & $\mathrm{m}$ & $\operatorname{tr}$ & & & Rec:tr & \\
\hline MP3127 W & $43,4 \mathrm{~m}$ & $\mathrm{~m}$ & $\operatorname{tr}$ & $\mathrm{m}$ & $\mathrm{m}$ & M & & & Dol:M & Argillaceous limestone \\
\hline$<2 \mu \mathrm{m}$ & & M & M & $\mathrm{m}$ & $\mathrm{m}$ & $\mathrm{m}$ & & & Dol:m & \\
\hline MP3125 W & $42,8 \mathrm{~m}$ & $\mathrm{~m}$ & $\operatorname{tr}$ & $\mathrm{m}$ & $\mathrm{m}$ & M & & & & Argillaceous limestone \\
\hline$<2 \mu \mathrm{m}$ & & M & M & $\mathrm{m}$ & $\mathrm{m}$ & M & & & & \\
\hline MP3123 W & $42,26 \mathrm{~m}$ & $\operatorname{tr}$ & $\operatorname{tr}$ & & $\mathrm{m}$ & M & & & Dol:m & Limestone \\
\hline$<2 \mu \mathrm{m}$ & & M & M & $\mathrm{m}$ & $\mathrm{m}$ & M & & & Dol:m, Rec:tr & \\
\hline
\end{tabular}


Table 2 (continued)

\begin{tabular}{|c|c|c|c|c|c|c|c|c|c|c|}
\hline \multicolumn{11}{|c|}{ CORCAL QUARRY } \\
\hline SAMPLE & LEVEL & Sme & Chl & Ill & $\mathrm{Qz}$ & Cal & $\mathrm{Ab}$ & Gth & Others & Lithotype \\
\hline MP3121 W & $41,66 \mathrm{~m}$ & $\mathrm{~m}$ & $\mathrm{~m}$ & $\operatorname{tr}$ & $\mathrm{M}$ & M & & $\operatorname{tr}$ & Dol:tr & Calcite mudrock \\
\hline$<2 \mu \mathrm{m}$ & & M & $\mathrm{M}$ & $\mathrm{m}$ & $\operatorname{tr}$ & $\operatorname{tr}$ & & $\operatorname{tr}$ & Rec:tr & \\
\hline MP3120 W & $41,46 \mathrm{~m}$ & $\operatorname{tr}$ & $\operatorname{tr}$ & & $\mathrm{M}$ & $\mathrm{M}$ & & $\operatorname{tr}$ & Dol:tr & Calcite mudrock \\
\hline$<2 \mu \mathrm{m}$ & & M & M & M & $\mathrm{m}$ & $\operatorname{tr}$ & & $\operatorname{tr}$ & Dol:tr, Rec:tr & \\
\hline MP3119 W & $41,06 \mathrm{~m}$ & M & $\mathrm{m}$ & M & M & & & $\operatorname{tr}$ & & Mudrock \\
\hline$<2 \mu \mathrm{m}$ & & M & M & M & $\mathrm{m}$ & & & $\operatorname{tr}$ & Crr:tr & \\
\hline MP3118 W & $40,78 \mathrm{~m}$ & $\mathrm{~m}$ & $\mathrm{~m}$ & $\operatorname{tr}$ & $\mathrm{M}$ & $\operatorname{tr}$ & & $\operatorname{tr}$ & Rec:tr & Mudrock \\
\hline$<2 \mu \mathrm{m}$ & & M & M & M & $\mathrm{m}$ & & & $\operatorname{tr}$ & Rec:tr & \\
\hline MP3117 W & $40,51 \mathrm{~m}$ & $\mathrm{~m}$ & $\mathrm{~m}$ & $\operatorname{tr}$ & M & $\mathrm{m}$ & & $\operatorname{tr}$ & Rec:tr & Calcite mudrock \\
\hline$<2 \mu \mathrm{m}$ & & M & M & M & $\mathrm{m}$ & $\operatorname{tr}$ & & $\operatorname{tr}$ & Rec:tr & \\
\hline MP3116 W & $40,5 \mathrm{~m}$ & & & & $\mathrm{~m}$ & M & & & & Limestome \\
\hline MP3115 W & $40,49 \mathrm{~m}$ & $\operatorname{tr}$ & $\operatorname{tr}$ & $\operatorname{tr}$ & $\mathrm{m}$ & $\mathrm{M}$ & & $\operatorname{tr}$ & & Argillaceous limestone \\
\hline$<2 \mu \mathrm{m}$ & & M & M & M & $\mathrm{m}$ & $\operatorname{tr}$ & & $\operatorname{tr}$ & & \\
\hline \multicolumn{11}{|c|}{ LAGINHA QUARRY } \\
\hline SAMPLE & LEVEL & Sme & Chl & Ill & Qz & Cal & $\mathbf{A b}$ & Gth & Others & Lithotype \\
\hline MP3264 W & $82,56 \mathrm{~m}$ & & M & M & M & & $\mathrm{m}$ & & & Siltstone \\
\hline$<2 \mu \mathrm{m}$ & & & M & M & $\mathrm{m}$ & & $\operatorname{tr}$ & & & \\
\hline MP3262 W & $81,6 \mathrm{~m}$ & & M & M & $\mathrm{M}$ & & $\mathrm{m}$ & & & Siltstone \\
\hline$<2 \mu \mathrm{m}$ & & & M & M & $\mathrm{m}$ & & $\operatorname{tr}$ & & & \\
\hline MP3260 W & $81 \mathrm{~m}$ & & M & $\mathrm{m}$ & $\mathrm{M}$ & & $\mathrm{m}$ & & & Siltstone \\
\hline$<2 \mu \mathrm{m}$ & & $\operatorname{tr}$ & M & M & $\mathrm{m}$ & & $\operatorname{tr}$ & & & \\
\hline MP3258 W & $80,3 \mathrm{~m}$ & & M & $\mathrm{m}$ & $\mathrm{M}$ & & $\mathrm{m}$ & & & Siltstone \\
\hline$<2 \mu \mathrm{m}$ & & $\operatorname{tr}$ & M & M & $\mathrm{m}$ & & $\operatorname{tr}$ & & & \\
\hline MP3257 W & $79,75 \mathrm{~m}$ & & M & $\mathrm{m}$ & $\mathrm{M}$ & & $\mathrm{m}$ & & $\mathrm{Dol}=\mathrm{m}$ & Siltstone \\
\hline$<2 \mu \mathrm{m}$ & & $\operatorname{tr}$ & M & M & $\mathrm{m}$ & & $\operatorname{tr}$ & & $\mathrm{Dol}=\operatorname{tr}$ & \\
\hline MP3256 W & $79,45 \mathrm{~m}$ & & M & $\mathrm{m}$ & $\mathrm{M}$ & & $\mathrm{m}$ & & & Siltstone \\
\hline$<2 \mu \mathrm{m}$ & & $\operatorname{tr}$ & M & M & $\mathrm{m}$ & & $\operatorname{tr}$ & & $\mathrm{Crr}=\mathrm{tr}$ & \\
\hline MP3255 W & $79,3 \mathrm{~m}$ & & $\mathrm{~m}$ & $\mathrm{~m}$ & $\mathrm{M}$ & $\operatorname{tr}$ & $\mathrm{m}$ & & & Siltstone \\
\hline$<2 \mu \mathrm{m}$ & & $\operatorname{tr}$ & M & M & $\mathrm{m}$ & & $\operatorname{tr}$ & & & \\
\hline MP3254 W & $78,84 \mathrm{~m}$ & & M & $\mathrm{m}$ & $\mathrm{M}$ & & $\mathrm{m}$ & & & Siltstone \\
\hline$<2 \mu \mathrm{m}$ & & $\operatorname{tr}$ & M & M & $\mathrm{m}$ & & $\operatorname{tr}$ & & $\mathrm{Crr}=\mathrm{tr}$ & \\
\hline MP3252 W & $78,28 \mathrm{~m}$ & & M & $\mathrm{m}$ & $\mathrm{M}$ & & $\mathrm{m}$ & & & Siltstone \\
\hline$<2 \mu \mathrm{m}$ & & $\operatorname{tr}$ & M & M & $\mathrm{m}$ & & $\operatorname{tr}$ & & $\mathrm{Crr}=\mathrm{tr}$ & \\
\hline MP3250 W & $77,58 \mathrm{~m}$ & & M & $\mathrm{m}$ & $\mathrm{M}$ & & $\mathrm{m}$ & & & Siltstone \\
\hline$<2 \mu \mathrm{m}$ & & $\operatorname{tr}$ & M & M & $\mathrm{m}$ & & $\operatorname{tr}$ & & $\mathrm{Crr}=\mathrm{tr}$ & \\
\hline MP3248 W & $76,9 \mathrm{~m}$ & & M & $\mathrm{m}$ & $\mathrm{M}$ & & $\mathrm{m}$ & & & Siltstone \\
\hline$<2 \mu \mathrm{m}$ & & & M & M & $\mathrm{m}$ & & $\operatorname{tr}$ & & & \\
\hline MP3246 W & $76,28 \mathrm{~m}$ & & M & $\mathrm{m}$ & $\mathrm{M}$ & & $\mathrm{m}$ & & & Siltstone \\
\hline$<2 \mu \mathrm{m}$ & & & M & M & $\mathrm{m}$ & & $\operatorname{tr}$ & & & \\
\hline MP3244 W & $75,56 \mathrm{~m}$ & & M & $\mathrm{m}$ & $\mathrm{M}$ & & $\mathrm{m}$ & & & Siltstone \\
\hline$<2 \mu \mathrm{m}$ & & $\operatorname{tr}$ & M & M & $\mathrm{m}$ & & $\operatorname{tr}$ & & $\mathrm{Crr}=\mathrm{tr}$ & \\
\hline MP3242 W & $74,9 \mathrm{~m}$ & & M & $\mathrm{m}$ & $\mathrm{M}$ & & $\mathrm{m}$ & & & Siltstone \\
\hline$<2 \mu \mathrm{m}$ & & $\operatorname{tr}$ & M & M & $\mathrm{m}$ & & $\operatorname{tr}$ & & & \\
\hline MP3241 W & $74,56 \mathrm{~m}^{*}$ & & M & $\mathrm{m}$ & $\mathrm{M}$ & & $\mathrm{m}$ & & & Siltstone \\
\hline$<2 \mu \mathrm{m}$ & & & M & M & $\mathrm{m}$ & & $\operatorname{tr}$ & & $\mathrm{Crr}=\mathrm{tr}$ & \\
\hline MP3239 W & $73,84 \mathrm{~m}^{*}$ & & M & $\mathrm{m}$ & $\mathrm{M}$ & & $\mathrm{m}$ & & & Siltstone \\
\hline$<2 \mu \mathrm{m}$ & & $\operatorname{tr}$ & M & M & $\mathrm{m}$ & & $\operatorname{tr}$ & & $\mathrm{Crr}=\mathrm{tr}$ & \\
\hline MP3237 W & $73,28 \mathrm{~m}^{*}$ & & M & $\mathrm{m}$ & $\mathrm{M}$ & & $\mathrm{m}$ & & & Siltstone \\
\hline$<2 \mu \mathrm{m}$ & & & M & M & $\mathrm{m}$ & & $\operatorname{tr}$ & & & \\
\hline MP3235 W & $72,56 \mathrm{~m}$ & & M & $\mathrm{m}$ & $\mathrm{M}$ & & $\mathrm{m}$ & & & Siltstone \\
\hline$<2 \mu \mathrm{m}$ & & $\operatorname{tr}$ & M & M & $\mathrm{m}$ & & $\operatorname{tr}$ & & $\mathrm{Crr}=\mathrm{tr}$ & \\
\hline MP3233 W & $71,9 \mathrm{~m}$ & & M & $\mathrm{m}$ & $\mathrm{M}$ & & $\mathrm{m}$ & & & Siltstone \\
\hline$<2 \mu \mathrm{m}$ & & & M & M & $\mathrm{m}$ & & $\operatorname{tr}$ & & & \\
\hline MP3231 W & $71,56 \mathrm{~m}$ & & M & $\mathrm{m}$ & $\mathrm{M}$ & & $\mathrm{m}$ & & & Siltstone \\
\hline$<2 \mu \mathrm{m}$ & & & M & M & $\mathrm{m}$ & & $\operatorname{tr}$ & & & \\
\hline MP3229 W & $70,84 \mathrm{~m}$ & & M & $\mathrm{m}$ & $\mathrm{M}$ & & $\mathrm{m}$ & & & Siltstone \\
\hline$<2 \mu \mathrm{m}$ & & & M & M & $\mathrm{m}$ & & $\operatorname{tr}$ & & & \\
\hline MP3227 W & $70,28 \mathrm{~m}$ & & M & $\mathrm{m}$ & $\mathrm{M}$ & & $\mathrm{m}$ & & & Siltstone \\
\hline$<2 \mu \mathrm{m}$ & & $\operatorname{tr}$ & M & M & $\mathrm{m}$ & & $\operatorname{tr}$ & & $\mathrm{Crr}=\mathrm{tr}$ & \\
\hline MP3226 W & $69,72 \mathrm{~m}$ & & M & $\mathrm{m}$ & $\mathrm{m}$ & & $\mathrm{m}$ & & & Siltstone \\
\hline$<2 \mu \mathrm{m}$ & & $\operatorname{tr}$ & M & M & $\mathrm{m}$ & & $\operatorname{tr}$ & & $\mathrm{Crr}=\mathrm{tr}$ & \\
\hline MP3224 W & $69,28 \mathrm{~m}$ & & M & $\mathrm{m}$ & $\mathrm{M}$ & & $\mathrm{m}$ & & & Siltstone \\
\hline$<2 \mu \mathrm{m}$ & & & M & M & $\mathrm{m}$ & & $\operatorname{tr}$ & & & \\
\hline MP3223 W & $69 \mathrm{~m}$ & & M & $\mathrm{m}$ & $\mathrm{M}$ & & $\mathrm{m}$ & & & Siltstone \\
\hline$<2 \mu \mathrm{m}$ & & & M & M & $\mathrm{m}$ & & $\operatorname{tr}$ & & Gp:tr & \\
\hline MP3222 W & $68,84 \mathrm{~m}$ & & M & $\mathrm{m}$ & $\mathrm{m}$ & & $\mathrm{m}$ & & & Siltstone \\
\hline$<2 \mu \mathrm{m}$ & & $\operatorname{tr}$ & M & M & $\mathrm{m}$ & & $\operatorname{tr}$ & & & \\
\hline MP3220 W & $68,28 \mathrm{~m}$ & & M & $\mathrm{m}$ & $\mathrm{m}$ & & $\mathrm{m}$ & & & Siltstone \\
\hline$<2 \mu \mathrm{m}$ & & $\operatorname{tr}$ & M & M & $\mathrm{m}$ & & $\operatorname{tr}$ & & & \\
\hline MP3218 W & $67,53 \mathrm{~m}$ & & M & $\mathrm{m}$ & $\mathrm{M}$ & & $\mathrm{m}$ & & & Siltstone \\
\hline$<2 \mu \mathrm{m}$ & & $\operatorname{tr}$ & $\mathrm{m}$ & M & $\mathrm{m}$ & & $\operatorname{tr}$ & & & \\
\hline & & & & & & & & & & (continued on $n$ \\
\hline
\end{tabular}


Table 2 (continued)

\begin{tabular}{|c|c|c|c|c|c|c|c|c|c|c|}
\hline \multicolumn{11}{|c|}{ CORCAL QUARRY } \\
\hline SAMPLE & LEVEL & Sme & Chl & Ill & $\mathrm{Qz}$ & Cal & $\mathrm{Ab}$ & Gth & Others & Lithotype \\
\hline MP3216 W & $66,84 \mathrm{~m}$ & & M & $\mathrm{m}$ & $\mathrm{M}$ & & $\mathrm{m}$ & & & Siltstone \\
\hline$<2 \mu \mathrm{m}$ & & $\operatorname{tr}$ & M & M & $\mathrm{m}$ & & $\operatorname{tr}$ & & & \\
\hline MP3212 W & $65,56 \mathrm{~m}$ & & M & $\mathrm{m}$ & M & & $\mathrm{m}$ & & & Siltstone \\
\hline$<2 \mu \mathrm{m}$ & & $\operatorname{tr}$ & M & M & $\mathrm{m}$ & & $\operatorname{tr}$ & & & \\
\hline MP3210 W & $64,86 \mathrm{~m}$ & & M & $\mathrm{m}$ & M & $\operatorname{tr}$ & $\mathrm{m}$ & & & Siltstone \\
\hline$<2 \mu \mathrm{m}$ & & $\operatorname{tr}$ & M & M & $\mathrm{m}$ & & $\operatorname{tr}$ & & & \\
\hline MP3208 W & $64,3 \mathrm{~m}$ & & M & $\mathrm{m}$ & $\mathrm{M}$ & $\operatorname{tr}$ & $\mathrm{m}$ & & & Siltstone \\
\hline$<2 \mu \mathrm{m}$ & & $\mathrm{m}$ & M & M & $\mathrm{m}$ & & $\operatorname{tr}$ & & & \\
\hline MP3206 W & $63,56 \mathrm{~m}$ & & M & $\mathrm{m}$ & $\mathrm{M}$ & & $\mathrm{m}$ & & & Siltstone \\
\hline$<2 \mu \mathrm{m}$ & & $\mathrm{m}$ & M & M & $\mathrm{m}$ & & $\mathrm{m}$ & & $\mathrm{Crr}=\mathrm{tr}$ & \\
\hline MP3204 W & $62,76 \mathrm{~m}$ & & M & M & M & & $\mathrm{m}$ & & & Siltstone \\
\hline$<2 \mu \mathrm{m}$ & & $\mathrm{m}$ & M & M & $\mathrm{m}$ & & $\mathrm{m}$ & & $\mathrm{Crr}=\mathrm{tr}$ & \\
\hline MP3202 W & $62,3 \mathrm{~m}$ & & M & M & $\mathrm{M}$ & & $\mathrm{m}$ & & Gp:tr & Siltstone \\
\hline$<2 \mu \mathrm{m}$ & & $\mathrm{m}$ & M & M & $\mathrm{m}$ & & $\mathrm{m}$ & & Gp:tr & \\
\hline MP3200 W & $61,76 \mathrm{~m}$ & & M & M & $\mathrm{m}$ & & & & Gp:tr & Siltstone \\
\hline$<2 \mu \mathrm{m}$ & & $\mathrm{m}$ & M & M & M & & & & Gp:tr & \\
\hline MP3198 W & $61,2 \mathrm{~m}$ & & M & M & $\mathrm{m}$ & & & & & Siltstone \\
\hline$<2 \mu \mathrm{m}$ & & $\mathrm{m}$ & M & M & $\mathrm{m}$ & & & & $\mathrm{Crr}=\mathrm{tr}$ & \\
\hline MP3196 W & $60,56 \mathrm{~m}$ & & M & M & $\mathrm{M}$ & & & & Gp:tr & Siltstone \\
\hline$<2 \mu \mathrm{m}$ & & $\mathrm{m}$ & M & M & $\mathrm{m}$ & & & & Gp:tr & \\
\hline MP3194 W & $60,38 \mathrm{~m}$ & & M & M & M & & & & $\mathrm{Jrs}=\mathrm{tr} ; \mathrm{Gp}: \mathrm{tr}$ & Siltstone \\
\hline$<2 \mu \mathrm{m}$ & & $\mathrm{m}$ & M & M & $\mathrm{m}$ & & & & Gp:tr & \\
\hline MP3192 W & $59,73 \mathrm{~m}$ & M & & M & $\mathrm{M}$ & & & & $\mathrm{K} \ln =\mathrm{m}$ & Siltstone \\
\hline$<2 \mu \mathrm{m}$ & & M & & M & $\mathrm{m}$ & & & & $\mathrm{Kln}=\mathrm{m} ; \mathrm{Crr}=\mathrm{tr}$ & \\
\hline MP3190 W & $59,28 \mathrm{~m}$ & $\operatorname{tr}$ & & $\mathrm{m}$ & M & $\operatorname{tr}$ & & & $\mathrm{Kln}=\mathrm{m}$ & Siltstone \\
\hline$<2 \mu \mathrm{m}$ & & M & & M & $\mathrm{m}$ & & & & $\mathrm{Kln}=\mathrm{m} ; \mathrm{Crr}=\mathrm{tr}$ & \\
\hline MP3189 W & $59,1 \mathrm{~m}$ & $\mathrm{~m}$ & $\operatorname{tr}$ & M & $\mathrm{M}$ & $\operatorname{tr}$ & & & Kln = M; Verm:tr Gp:M & Siltstone \\
\hline$<2 \mu \mathrm{m}$ & & $\mathrm{m}$ & $\operatorname{tr}$ & M & $\mathrm{m}$ & $\operatorname{tr}$ & & & & \\
\hline \multicolumn{11}{|c|}{ OUTCROP ALONG MS-243 } \\
\hline SAMPLE & & Sme & Chl & Ill & Qz & Cal & $\mathbf{A b}$ & Gth & Others & Lithotype \\
\hline GG1 W & & & $\operatorname{tr}$ & $\mathrm{m}$ & M & $\mathrm{m}$ & $\mathrm{m}$ & & & Siltstone \\
\hline$<2 \mu \mathrm{m}$ & & & $\mathrm{m}$ & M & M & $\mathrm{m}$ & $\mathrm{m}$ & & Vrm:tr & \\
\hline MP $3809 \mathrm{~W}$ & & & M & M & M & $\operatorname{tr}$ & $\mathrm{m}$ & & & Siltstone \\
\hline$<2 \mu \mathrm{m}$ & & & $\mathrm{m}$ & M & M & & $\mathrm{m}$ & & Vrm:tr & \\
\hline
\end{tabular}

quartz, smectite, chlorite and illite as major components. Clay fraction is composed by smectite, illite and chlorite as major to minor components. Locally, there is a variable contribution of calcite and dolomite as well as quartz, goethite, albite, pyrite and gypsum.

At Corcal quarry, the mudrocks of L7 have similar mineral composition to the ones interbedded in carbonate layers (Table 2). In whole rock, quartz is a major component, such as smectite and calcite, in some samples, while illite and chlorite are minor components (Fig. 10A). In clay fraction, smectite, chlorite and illite are major components whereas quartz, calcite and dolomite are minor components (Fig. 9A). Characteristic peaks of smectite are well defined, narrow, symmetric and with great intensity (Fig. 9A). The mixed-layer clay minerals rectorite (Sme-Ill, $\mathrm{d} \approx 24 \AA$ ) and corrensite (Chl-Sme, $\mathrm{d} \approx 28 \AA$ ) are trace components and rarely are minor components. Goethite occurs as a trace component both in whole rock and in clay fraction.

At the Laginha quarry and at outcrop along MS-243, mineral composition of siliciclastic siltstones is slightly distinct from the mudrocks interbedded in carbonate layers (Table 2; Fig. 9B and 9. C). In whole rock, besides quartz, illite and chlorite as major to minor components, there is also albite. In clay fraction, illite and chlorite are major components while quartz and albite occur as major or minor components. If smectite occurs, it is a trace component and presents its characteristic peaks poorly defined, asymmetric, wide and with low intensity (Fig. 9B). The mixed-layer clay mineral corrensite (Chl-Sme) is rare as a trace component and dolomite occurs rarely as a minor and a trace component, in whole rock and clay fraction, respectively. At outcrop along MS-243, vermiculite occurs as a trace component and can relate to superficial alteration. Additionally, calcite occurs rarely as a trace component at this quarry and as minor component at the outcrop along
MS-243 and this presence can be related to fine veins.

Siltstones in the first meter above the contact with limestones at Laginha quarry present distinct features of the overlying siltstone package. In whole rock analyses (Fig. 10B - MP3192, Table 2) quartz, illite, kaolinite and smectite are major components. At sample MP3189, $10 \mathrm{~cm}$ above the contact, gypsum is a major component along with quartz, illite and kaolinite, and vermiculite and calcite are trace components. In clay fraction, illite is the major component and quartz and kaolinite are minor ones. Smectite occurs as major to minor component and its characteristic peaks are well defined, narrow and with great intensity (Fig. 10B- MP3192). Chlorite and vermiculite are trace component.

\subsection{Chemical composition (XRF)}

The major oxides compositions, defined by XRF, of the mudrocks associated to carbonate layers of the Tamengo Formation and mudrocks and siltstones of the superior portions of Laginha and Corcal quarry and the outcrop along MS-243 are broadly similar, except for $\mathrm{Na}_{2} \mathrm{O}$ content (Table 3). They all have a silica-alumina nature in which $\mathrm{SiO}_{2}$ and $\mathrm{Al}_{2} \mathrm{O}_{3}$ contents vary, respectively, from 47.3 to $65.07 \%$ and from 14.06 to $17.94 \%$, without showing a clear trend, not evident also in the values of $\mathrm{Fe}_{2} \mathrm{O}_{3}$ (5.14-7.97\%), $\mathrm{MgO}(1.71-5.79 \%)$ and $\mathrm{K}_{2} \mathrm{O}(3.01-5.74 \%)$. However, $\mathrm{Na}_{2} \mathrm{O}$ content is less than $0.1 \%$ in the mudrocks, even in the upper part of Corcal quarry (L7), while is greater than $1.0 \%$ in the siltstones of Laginha quarry and of the outcrop along MS-243. 

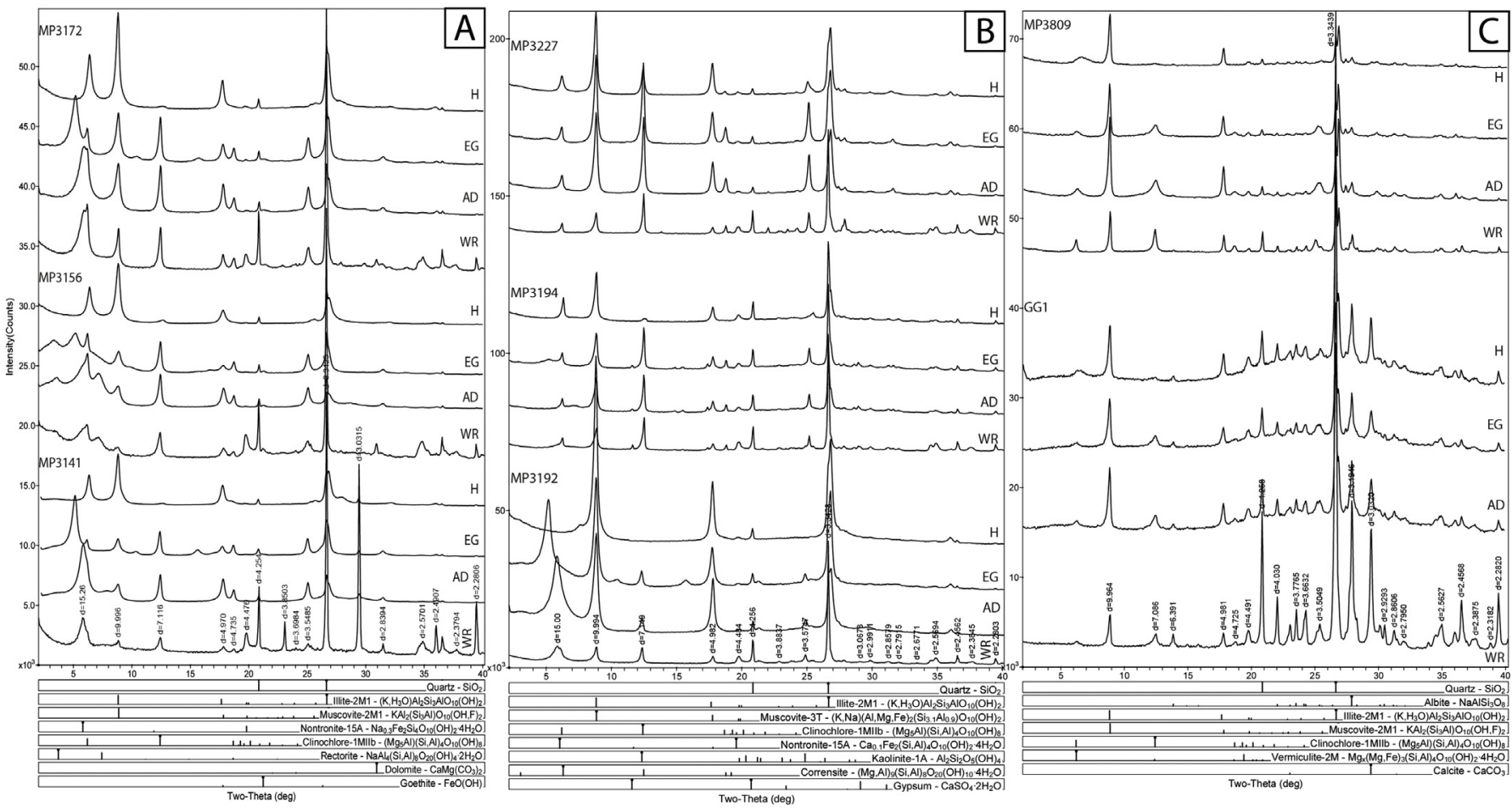

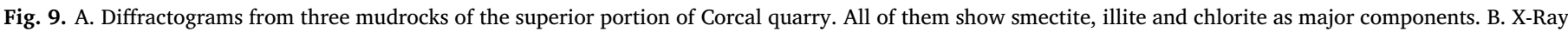

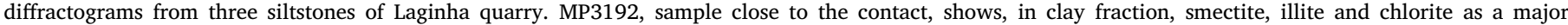

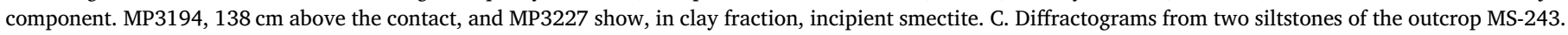

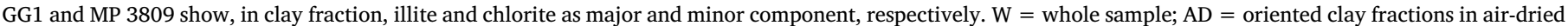
conditions; $\mathrm{EG}=$ after ethylene-glycol saturation; $\mathrm{H}=$ after heating.

\section{Discussion}

Based on the results obtained in this work, the stratigraphic relationship of the Tamengo and Guaicurus formations at Corumbá region is discussed, as well as considerations on depositional environment based on mineral and chemical composition of the pelitic rocks.
5.1. Sedimentary constrains to define stratigraphic relationship between the Tamengo and Guaicurus formations

Characteristics of carbonate layers and microfossils of mudrocks interbedded within, belonging to Tamengo Formation, had been recorded in Boggiani et al. (2010), Oliveira (2010), Walde et al. (2015) and Adorno et al. (2017).

The present paper shows the sedimentological features, mineralogical and chemical compositions of mudrocks and siltstones that

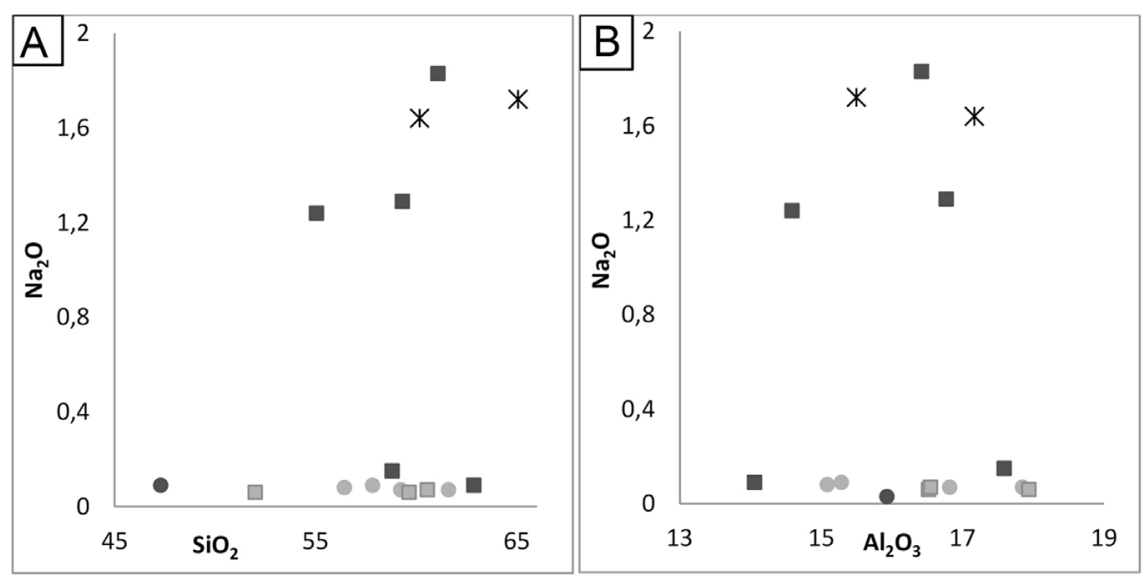

- Corcal quarry - Tamengo Fm

Corcal quarry - (assign to) Guaicurus Fm

- Laginha quarry - Tamengo Fm

- Laginha quarry - Guaicurus Fm

* Outcrop along MS-243 - Guaicurus Fm
Fig. 10. Binary diagrams of $\mathrm{Na}_{2} \mathrm{O}$ versus $\mathrm{SiO}_{2}$ and versus $\mathrm{Al}_{2} \mathrm{O}_{3}$. Both diagrams suggest separation in two groups. Light gray circles and squares: samples from Corcal quarry of Tamengo Formation and assign to Guaicurus Formation, respectively. Dark gray circle and squares: samples from Laginha quarry of Tamengo Formation and of Guaicurus Formation. Asterisk: samples from outcrop along MS-243. 
Table 3

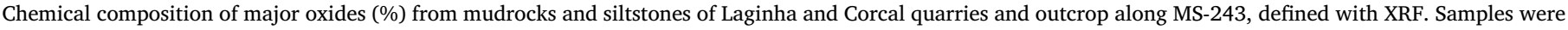
analyzed at CRTI/UFG and/or UnB. ${ }^{\text {a: }}$ analyzed at CRTI/UFG; ${ }^{\text {b: }}$ analyzed at UnB; ${ }^{\text {c }}$ : analyzed at both CRTI/UFG and UnB.

\begin{tabular}{|c|c|c|c|c|c|c|c|c|c|c|c|c|c|c|c|}
\hline & \multicolumn{7}{|c|}{ CORCAL QUARRY } & \multicolumn{6}{|c|}{ LAGINHA QUARRY } & \multicolumn{2}{|c|}{ MS-243 } \\
\hline & ${ }^{\mathrm{a}} \mathrm{MP}$ & ${ }^{\mathrm{a}} \mathrm{MP}$ & ${ }^{\mathrm{a}} \mathrm{MP}$ & ${ }^{\mathrm{a}} \mathrm{MP}$ & ${ }^{\mathrm{c}} \mathrm{MP}$ & ${ }^{\mathrm{c}} \mathrm{MP}$ & ${ }^{\mathrm{a}} \mathrm{MP}$ & ${ }^{\mathrm{b}} \mathrm{MP}$ & ${ }^{\mathrm{c}} \mathrm{MP}$ & ${ }^{\mathrm{c}} \mathrm{MP}$ & ${ }^{\mathrm{a}} \mathrm{MP}$ & ${ }^{\mathrm{c}} \mathrm{MP}$ & ${ }^{\mathrm{c}} \mathrm{MP}$ & ${ }^{\mathrm{c}} \mathrm{MP}$ & ${ }^{\mathrm{a}} \mathrm{MP}$ \\
\hline & 1635 & 1639 & 1641 & 1643 & 3156 & 3172 & 3183 & 1658 & 3190 & 3194 & 3212 & 3227 & 3262 & GG1 & 3809 \\
\hline $\mathrm{SiO}_{2}$ & 59.23 & 61.61 & 56.43 & 57.84 & 52,00 & 60.55 & 59.65 & 47.32 & 62.87 & 58.81 & 55.04 & 59.32 & 61.08 & 65.07 & 60.17 \\
\hline $\mathrm{TiO}_{2}$ & 0.91 & 0.94 & 0.82 & 0.87 & 0.71 & 0.85 & 0.79 & 1.27 & 0.68 & 0.83 & 0.68 & 0.83 & 0.85 & 0.79 & 0.84 \\
\hline $\mathrm{Al}_{2} \mathrm{O}_{3}$ & 17.85 & 16.82 & 15.09 & 15.29 & 16.52 & 16.55 & 17.94 & 15.93 & 14.06 & 17.59 & 14.59 & 16.77 & 16.42 & 15.5 & 17.17 \\
\hline $\mathrm{Fe}_{2} \mathrm{O}_{3}$ & 7.71 & 7.06 & 5.87 & 6.29 & 6.20 & 7.97 & 7.20 & 7.51 & 5.14 & 6.83 & 7.25 & 7.61 & 6.94 & 6.04 & 7.31 \\
\hline $\mathrm{MnO}$ & 0.04 & 0.04 & 0.04 & 0.06 & 0.05 & 0.04 & 0.05 & 0.03 & 0.06 & 0.02 & 0.19 & 0.16 & 0.11 & 0.04 & 0.06 \\
\hline $\mathrm{MgO}$ & 3.35 & 3.33 & 2.99 & 2.94 & 5.79 & 3.67 & 3.93 & 2.98 & 1.71 & 2.67 & 3.28 & 3.16 & 2.97 & 2.53 & 3.02 \\
\hline $\mathrm{CaO}$ & 0.35 & 0.39 & 5.67 & 4.76 & 4.00 & 0.40 & 0.50 & 15.36 & 4.59 & 0.46 & 4.85 & 1.31 & 0.97 & 0.51 & 0.61 \\
\hline $\mathrm{Na}_{2} \mathrm{O}$ & 0.07 & 0.07 & 0.08 & 0.09 & 0.06 & 0.07 & 0.06 & 0.03 & 0.09 & 0.15 & 1.24 & 1.29 & 1.83 & 1.72 & 1.64 \\
\hline $\mathrm{K}_{2} \mathrm{O}$ & 4.43 & 3.73 & 3.16 & 3.20 & 3.01 & 3.49 & 4.12 & 5.74 & 3.05 & 4.38 & 3.41 & 3.85 & 3.66 & 3.60 & 4.18 \\
\hline $\mathrm{P} 2 \mathrm{O} 5$ & 0.10 & 0.07 & 0.08 & 0.09 & 0.02 & 0.05 & 0.05 & 0.09 & 0.68 & 0.10 & 0.16 & 0.15 & 0.17 & 0.23 & 0.16 \\
\hline $\mathrm{SO}_{3}$ & $<$ & $<$ & $<$ & 0.16 & $<$ & $<$ & $<$ & $<$ & $<$ & 0.12 & 0.25 & $<$ & $<$ & $<$ & $<$ \\
\hline LOI & 5.47 & 5.31 & 8.99 & 8.40 & 11.08 & 5.54 & 5.54 & 11.80 & 6.83 & 7.49 & 8.38 & 5.38 & 4.67 & 3.71 & 3.92 \\
\hline$\Sigma$ & 99.52 & 99.37 & 99.24 & 100 & 99.42 & 99.18 & 99.82 & 99.99 & 99.76 & 99.46 & 99.31 & 99.81 & 99.67 & 99.75 & 99.08 \\
\hline
\end{tabular}

allowed distinguish the pelitic rocks of both formations: Tamengo and Guaicurus.

The mudrocks interbedded in carbonate layers of Corcal and Laginha quarries can be carbonate, siliciclastic or mixed siliciclasticcarbonate mudrocks. They show irregular, generally discontinuous and curled, laminations of very fine material with frequent carbonate contribution. These rocks present fluid diffusion features (Fig. 7D and 7E) related to sub-vertical fractures, microveins and opaque material as organic matter within tortuously networks or filling millimetric druses (Fig. 7A). They also present, locally, calcite-filled laminae as gypsum pseudomorph (Fig. 7B), and biogenic mats (Fig. 7F). Mudrocks from the upper portion of Corcal quarry (L7; Fig. 8A-C) presents similar features to the ones observed at its inferior and medium portions, interbedded in carbonate layers.

Siltstones from the superior portion of Laginha quarry and from the outcrop along MS-243 present contrasting features to the underlying mudrocks interbedded with carbonate layers. Macroscopically, these bluish gray siltstones show homogeneous and continuous lamination and, under microscope, these laminations are defined by lamellar minerals and granular lamina, as well as opaque material films (Fig. 8DG). The siltstones are well sorted, uniform and present sub-horizontal quartz or calcite-filled fractures without fluid diffusion features.

The mineral composition of all mudrocks and siltstones is essentially detrital quartz, mica and diagenetic clay minerals. Mudrocks interbedded in carbonate layers have clay mineral paragenesis of illite + chlorite + smectite, all of them as major or minor component, as well as variable contribution of calcite, and rarely dolomite. L7 layer from Corcal quarry has the same mineral composition of mudrocks interbedded in carbonate layers. In contrast, siltstones from the superior portion of Laginha quarry and along MS-243 exhibit clay mineral paragenesis of illite + chlorite, characteristic of anchizone. These rocks are also composed of sporadic smectite as a trace component and albite as major or minor component in both whole rock and clay fraction.

The chemical composition show homogeneous values for all analyzed samples, except for $\mathrm{Na}_{2} \mathrm{O}$ content. The mudrocks interbedded with carbonate layers, including $\mathrm{L} 7$ from Corcal quarry, present values of $\mathrm{Na}_{2} \mathrm{O}$ below $0.1 \%$, whereas the siltstones from the upper portion of Laginha quarry and from the outcrop along MS-243 show $\mathrm{Na}_{2} \mathrm{O}$ contents higher than $1.0 \%$. Binary diagrams of $\mathrm{Na}_{2} \mathrm{O}$ values versus $\mathrm{SiO}_{2}$ (Fig. 10A) and versus $\mathrm{Al}_{2} \mathrm{O}_{3}$ (Fig. 10B) allow distinction in two separate groups: 1) mudrocks interbedded with carbonate layers from Laginha and Corcal quarries, along with the superior portion of the latter, and 2) siltstones of the superior portion of Laginha quarry and outcrop along MS-243.

The Tamengo Formation is presented entirely at Laginha quarry, as recorded in Boggiani (1998), including its superior contact with the Guaicurus Formation. Siltstones from the Guaicurus Formation, at this quarry, and at the outcrop along MS-243 present similar characteristics. However, the superior portion of Corcal quarry (L7), composed mainly by mudrocks, maintain similar petrographic, chemical and mineralogical characteristics to the mudrocks of its inferior and middle sections. Hence, the superior portion of Corcal quarry is considered to belong to the Tamengo Formation, contrary to the assertion by Boggiani et al. (2010).

Therefore, the stratigraphic positions of the Tamengo and Guaicurus formations can be defined by their sedimentary structures as well as their mineralogical and chemical compositions.

\subsection{Indicators of depositional environment}

The deposition of carbonate rocks of the Tamengo Formation is associated to microorganism activity and high evaporation rates (Oliveira, 2010), indicated by biogenic mats (Fig. 7F) and calcite as gypsum pseudomorph (Fig. 7B), respectively. Mudrock layers interbedded in carbonate layers, composed by detrital quartz, mica and diagenetic clay minerals, are a result of episodically immature siliciclastic supply, interrupting carbonate depositions. These sediments are derived from very fine-grained rocks of a nearby source area, under low intensity weathering, quickly transported and deposited. The source rocks of these siliciclastic supplies have a silica-alumina nature, with Na-poor content, relatively K-low and $\mathrm{Fe}-\mathrm{Mg}$ contribution, which lead to the diagenetic clay mineral paragenesis of illite + chlorite + smectite in the Tamengo Formation. The alternation of mudrocks and limestones argue that the depositional site remains almost the same, favoring carbonate deposition in the lack of siliciclastic supply.

The Guaicurus Formation consists of a thick and homogenous siltstone package and, in contrast to the Tamengo Formation, does not present carbonate intercalations. The siltstones are composed by detrital quartz, mica and diagenetic clay minerals, with paragenesis of illite + chlorite. These siltstones are persistently laminated, with wide lateral continuality and few flux structures, such as lens of fine grain, attesting to a water body environment below fair-weather waves. Rare synsedimentary structures, such as slumps, indicate instability in the sedimentary column. Siltstones of the Guaicurus Formation are a result of an uninterrupted immature siliciclastic supply from a nearby source area, composed by very fine-grained rocks, broadly similar to the Tamengo Formation.

The absence of carbonate rocks in the Guaicurus Formation and variations, in $\mathrm{Na}_{2} \mathrm{O}$ content - lower than $0.1 \%$ and higher than $1.0 \%$ in the Tamengo and Guaicurus formations, respectively - imply changes 
within the depositional condition, either the chemistry of the water or the source area. The difference in paleoenvironmental conditions from the Tamengo to Guaicurus formations denote an increase in water level and, consequently, lower energy setting. These modifications could be related to the tectonic setting of the Pan-African-Brasiliano Orogeny, which could have increased water level and exposed different rocks in the same nearby source area.

Previous researches argue that the Ediacaran-Cambrian transition remark chemical variations in shales related to the oxygenation events and increase of chemical weathering (Kennedy et al., 2006; Och and Shields-Zhou, 2012). As a result of these paleoenvironmental changes, a $\mathrm{K}_{2} \mathrm{O} / \mathrm{Al}_{2} \mathrm{O}_{3}$ decline is registered, related to an increase of expandable clay minerals and kaolinite (Cox et al., 1995; Kennedy et al., 2006). The clay mineral paragenesis found in the Tamengo and Guaicurus formations are essentially diagenetic and do not record these global indexes. At Corumbá region, local environmental could be influenced by a volcanic supply, such as evidenced by volcanic ashes dated by Babinski et al. (2008), possibly related to the breakup of the supercontinent Rodinia (Gernon et al., 2016; Lyu et al., 2017).

\subsection{Clay minerals as diagenetic indicators of the Tamengo and Guaicurus formations}

At Laginha quarry, the Tamengo and Guaicurus formations present an abrupt contact, defined by the dark gray carbonate rocks underlying $1 \mathrm{~m}$ of yellowish beige siltstones (Fig. 3C). These siltstones present anomalous features to the mudrocks underneath and to the siltstones above it. They are non-cohesive, with $\mathrm{Na}_{2} \mathrm{O}$ content of $0.09 \%$ and $0.15 \%$ and clay mineral paragenesis of smectite + illite. Additionally, kaolinite and gypsum occur indicating circulation of fluids. These can be connate fluids from the Tamengo Formation through the contact. Another hypothesis is alteration by post-depositional meteoric water interaction through the contact, between impermeable rocks. A third interpretation is that this interval could have been influenced by superficial weathering before the deposition of the Guaicurus Formation.

The rocks of Tamengo Formation present petrographic features of fluid diffusion, both in Laginha and Corcal quarries, as well as in others localities within Corumbá region (Guimarães et al., 2014). These evidences could lead to a fluid circulation event at Corumbá region, suggested by several authors. Trompette et al. (1998) and Angerer et al. (2016) related the mineralization in the Jacadigo Group (overlapped by the Corumbá Group) to hydrothermal fluids, or pore water flux. Piacentini et al. (2013) dated the metamorphic/hydrothermal event around 515Ma with the crystallization of muscovite. Specifically in the Tamengo Formation, Gaucher et al. (2003) suggested that a probable thermal event affected the preservation of organic walled microfossils.

Moreover, Tobias (2014) registered values of thermal alteration index (TAI) of palynomorphs, in the Tamengo Formation, indicating that the basin reached temperatures around $200{ }^{\circ} \mathrm{C}$, within the anchizone. This data is confirmed by the paragenesis of illite + chlorite + quartz and the absence of expandable minerals, which are characteristics of anchizone, as seen in siltstones of the Guaicurus Formation. Mudrocks from Tamengo Formation, however, present paragenesis of illite + chlorite + quartz with a major amount of smectite, which is associated to an early diagenetic stage. Therefore, mineral compositions of the Tamengo Formation are anomalous for progressive diagenetic processes. Aligned with the possibility of a fluid circulation event within this formation, the presence of smectite could indicate a retrograde diagenetic process (Nieto et al., 2005; Do Campo et al., 2017).

\section{Conclusion}

Mineralogical and chemical compositions along with the study of sedimentary structures could establish the stratigraphic positioning of the Tamengo and Guaicurus formations. Mudrocks interbedded in carbonate packages of Tamengo Formation are composed mainly by quartz, mica, illite, chlorite and smectite and present $\mathrm{Na}_{2} \mathrm{O}$ content lower than $0.1 \%$. Siltstones of Guaicurus Formation have similar mineral composition, except for the absence of smectite, and display $\mathrm{Na}_{2} \mathrm{O}$ content higher than 1\%. Hence, L1 to L7 layers of Corcal quarry expose rocks from the Tamengo Formation.

The Tamengo Formation was deposited in a favorable environment for deposition of carbonates, which was episodically interrupted by immature siliciclastic supply from very fine-grained rocks of a nearby source area. The Guaicurus Formation is a result of an uninterrupted immature siliciclastic supply from a nearby source area, composed by very fine-grained rocks. Chemical variations, however, are observed specially in $\mathrm{Na}_{2} \mathrm{O}$ content, higher in siltstones from the Guaicurus Formation, implying changes in the source area or in the chemistry of the water. The sediments of the Guaicurus Formation were deposited under a low energy setting in a high water level, below fair-weather wave.

Diagenetic clay mineral paragenesis - illite, chlorite - characterize anchizone stage in both formations. However, petrographic features within the Tamengo Formation indicate a fluid circulation event and, aligned with the occurrence of a major amount of smectite, could determine a retrograde diagenesis, forming this anomalous paragenesis.

\section{Acknowledgements}

This study was financed in part by the Coordenação de Aperfeiçoamento de Pessoal de Nível Superior - Brasil (CAPES) Finance Code 001 - and also had the support of Project EDIACARANO, a partnership between ANP (National Agency for Petroleum, Gas and Biofuels)/PETROBRÁS (Petróleo Brasileiro S.A.)/FINATEC. We thank the UFMS fellow researches, the mining companies Votorantim (ITAU) and Corcal, the engineering geologist Felisberto Santiago, the Brazilian Army and the Corumbá Fire Brigade for their support during field work.

\section{References}

Adorno, R.R., do Carmo, D.A., Germs, G., Walde, D.H.G., Denezine, M., Boggiani, P.C., Silva, S.C.S., Vasconcelos, J.R., Tobias, T.C., Guimarães, E.M., Vieira, L.C., Figueiredo, M.F., Moraes, R., Caminha, S.A., Suarez, P.A.Z., Rodrigues, C.V., Caixeta, G.M., Pinho, D., Schneider, G., Muyamba, R., 2017. Cloudina lucianoi (Beurlen\& Sommer, 1957), Tamengo Formation, ediacaran, Brazil: taxonomy, analysis of stratigraphic distribution and biostratigraphy. Precambrian Res. 301, 19-35. https://doi. org $/ 10.1016 /$ j.precamres.2017.08.023.

Almeida, F.F.M., 1964. Geologia do sudoeste mato-grossense. Boletim da Divisão de Geologia e Mineralogia, vol. 116. Departamento Nacional de Produção Mineral DNPM, pp. 1-18.

Almeida, F.F.M., 1965. Geologia da Serra da Bodoquena (Mato Grosso), Brasil. Boletim da Divisão de Geologia e Mineralogia, vol. 219. Departamento Nacional de Produção Mineral - DNPM, pp. 1-96.

Almeida, F.F.M., 1984. Província tocantins, setor sudoeste. In: de Almeida, F.F.M., Hasui, Y. (Eds.), O Pré-cambriano Do Brasil. Edgard Blücher, São Paulo, pp. 265-281.

Almeida, F.F.M., Mantovani, M.S.M., 1975. Geologia e geocronologia do granito de São Vicente, Mato Grosso. An. Acad. Bras. Ciênc. Rio de Janeiro, Brazil 47, 451-458.

Alvarenga, C.J.S., Trompette, R., 1992. Glacially influenced sedimentation in the late proterozoic of the paraguai belt (Mato Grosso, Brazil). Paleogeography, Paleoclimatology, Paleoecology 92 (1992), 85-105.

Alves, D.B., 1987. Desenvolvimento da metodologia de separação de amostras para análise difratométrica de argilominerais no Centro de Pesquisas da Petrobrás. Bol. Geociencias Petrobras 1 (2), 157-175.

Angerer, T., Hagemann, S.G., Walde, D.H.G., Halverson, G.P., Boyce, A.J., 2016. Multiple metal source in the glaciomarine facies of the Neoproterozoic Jacadigo iron formation in the "Santa Cruz deposits", Corumbá, Brazil. Precambrian Res. 275, 369-393. https://doi.org/10.1016/j.precamres.2016.01.002 0301-9268.

Babinski, M., Boggiani, P.C., Fanning, C.M., Fairchild, T.R., Simon, C.M., Sial, A.N., 2008. $\mathrm{U}-\mathrm{Pb}$ shrimp geochronology and isotope chemostratigraphy (C, O, Sr) of the Tamengo formation, southern Paraguay belt, Brazil. In: VI south American Symposium on isotope Geology. Anais.

Barbosa, O., 1949. Contribuição à geologia da região Brasil-Bolívia. Mineracao Metal. 13, 271-278.

Beurlen, K., Sommer, F.W., 1957. Observações estratigráficas e paleontológicas sobre o calcário de Corumbá. Boletim de Geologia e Mineralogia - DNPM. 168, 1-35.

Boggiani, P.C., 1998. Análise estratigráfica da Bacia Corumbá (Neoproterozóico) - Mato Grosso do Sul. 181p. Dissertação (Doutorado). Instituto de Geociências da Universidade de São Paulo, São Paulo.

Boggiani, P.C., Fairchild, T.R., Coimbra, A.M., 1993. O Grupo Corumbá 
(Neoproterozóico-Cambriano) na região central da Serra da Bodoquena (Faixa Paraguai), Mato Grosso do Sul. Rev. Bras. Geociencias 23, 301-305.

Boggiani, P.C., Alvarenga, C.J.S., 2004. Faixa Paraguai. Chapter 5. Org In: MantessoNeto, Bartorelli, A., Carneiro, C.D.R., Neves, B.B.B. (Eds.), Geologia do Continente Sul-Americano: Evolução da Obra de Fernando Fávio Marques de Almeida. Beca Produções Culturais Ltda, São Paulo, pp. 113-120.

Boggiani, P.C., Gaucher, C., SIAL, A.N., Babinski, M., Simon, C.M., Riccomini, C., Ferreira, V.P., Fairchild, T.R., 2010. Chemostratigraphy of the Tamengo Formation (Corumba group, Brasil): a contribution to the calibration of the ediacaran carbon-isotope curve. Precambrian Res. 182, 382-401. https://doi.org/10.1016/j.precamres.2010.06.003.

Campanha, G.A.C., Boggiani, P.C., Sallun FILHO, W., SÁ, F.R., Zuquim, M.P.S., Piacentini, T., 2011. A Faixa de Dobramentos Paraguai na Serra da Bodoquena e Depressão do Rio Miranda, Mato Grosso do Sul. Geol. Usp. Série Científica 11 (3), 79-96.

Campos, L.F.B., 2012. Diagênese das sequências Proterozóicas com base na caracterização de argilominerais - topo do Grupo Paranoá e base do Grupo Bambuí - Norte do Distrito Federal. 145p. Dissertação (Mestrado). Instituto de Geociências, Universidade de Brasília, Brasília.

Cox, R., Lowe, D.R., Cullers, R.L., 1995. The influence of sediment recycling and basement composition on evolution of mudrock chemistry in the southwestern United States. Geochem. Cosmochim. Acta 59 (14), 2919-2940. https://doi.org/10.1016/ 0016-7037(95)00185-9.

delgado, I.M., De Souza, J.D., DA Silva, L.C., DA Silveira Filho, N.C., Dos Santos, R.A., Pedreira, A.J., Guimarães, J.T., Angelim, L.A.A., Vasconcelos, A.M., Gomes, I.A., De Lacerda filho, J.V., valente, C.R., Perrotta, M.M., Heineck, C.A., 2003. Geotectônica do Escudo Atlântico. V. Bizzi, L. A., Schobbenhaus, C., Vidotti, R. M., Gonçalves, J. H. Geologia, Tectônica e Recursos Minerais do Brasil. CPRM, Brasília.

D'el-Rey Silva, L.J.H.D.R., Walde, D.H.G., Saldanha, D.O., 2016. The Neoproterozoic-Cambrian Paraguay Belt, central Brazil: Part I — new structural data and a new approach on the regional implications. Tectonophysics 676, 20-41. https://doi.org/10.1016/j.tecto.2016.03.019.

Do Campo, M., Nieto, F., Albanesi, G.L., Ortega, G., Monaldi, C.R., 2017. Outlining the thermal posdepositional evolution of the Ordovician successions of northwestern Argentina by clay mineral analysis, chlorite geothermometry and Kübler index. Andean Geol. 44 (2), 179-212. https://doi.org/10.5027/andgeoV44n2-a04.

Dunham, R.J., 1962. Classification of Carbonate Rocks According to Depositional Texture. American Association of Petroleum Geologists.

Fairchild, T.R., 1978. Evidências paleontológicas de uma possível idade Ediacariana ou Cambriana Inferior, para a parte leste do Grupo Corumbá (Mato Grosso do Sul). In: $30^{\circ}$ Congresso Brasileiro de Geologia, Resumo das Comunicações. Recife, pp. 181.

Fazio, G., Guimarães, E.M., Vieira, L.C., do Carmo, D.A., Walde, D.H.G., 2016. Composição mineral dos pelitos ediacaranos - formações Tamengo e Guaicurus (Grupo Corumbá) - e seu significado deposicional. In: 48ํㅡㄹ Congresso Brasileiro de Geologia. Anais. Porto Alegre (RS-Brasil), pp. 9-13 (de Outubro).

Fike, D.A., Grotzinger, J.P., Pratt, L.M., Summons, R.E., 2006. Oxidation of the Ediacaran Ocean, vol. 444. pp. 744-747. https://doi.org/10.1038/nature05345.

Flügel, E., 2004. Microfacies of Carbonate Rocks: Analysis, Interpretation and Application. Springer.

Fontanela, G.T., 2012. Dolomitização e Fosfogênese na Formação Bocaina, Grupo Corumbá (Ediacarano). 148p. Dissertação (Mestrado). Instituto de Geociências, Universidade de São Paulo, São Paulo.

Freitas, B.T., 2010. Tectônica e Sedimentação do Grupo Jagadigo (Neoproterozóico, MS). Instituto de Geociências da Universidade de São Paulo, São Paulo 144p. Dissertação (Mestrado).

Gaucher, C., Boggiani, P.C., Sprechmann, P., Sial, A.N., Fairchild, T., 2003. Integrated correlation of the Vendian to Cambrian Arroyo del Soldado and Corumbá Groups (Uruguay and Brazil): palaeogeographic, palaeoclimatic and palaeobiologic implications. Precambrian Res. 120, 241-278.

Gernon, T.M., Hincks, T.K., Tyrrell, T., Rohling, E.J., Palmer, M.R., 2016. Snowball Earth ocean chemistry driven by extensive ridge volcanism during Rodinia breakup. Nat. Geosci. 9, 242-248. https://doi.org/10.1038/NGEO2632.

Guimarães, E.M., Sampaio, L.F., Walde, D.H.G., do Carmo, D.A., 2013. Clay minerals of the ediacaran fossiliferous beds from Tamengo Formation (Corumba group, Brazil). In: Corumbá Meeting, Anais. Campo Grande e Corumbá (MS-Brasil), pp. 4-9 (de Agosto).

Guimarães, E.M., Vieira, L.C., do Carmo, D.A., Walde, D.H.G., Blois, C., 2014. Mineral composition of an ediacaran sequence: Cacimba escarpment (Tamengo Formation), Corumbá, MS - Brazil. In: A symposium and field workshop on Ediacaran and Cryogenian Stratigraphy. Anais. Yichang, Wuhan e Guiyang-Guilin (China), pp. 11-22 (de Junho).

Hahn, G., Hahn, R., Leonardos, O.H., Pflug, H.D., Walde, D.H.G., 1982. Körperlich erhaltene Scyphozoen-Reste aus dem Jungpräkambrium Brasiliens. Geologica et Paleontologica 16, 1-18.

Hidalgo, R.L.L., 2002. Análise micropaleontológica das formações Tamengo e Guaicurus, Grupo Corumbá (MS), e Formação Araras (MT), transição do NeoproterozóicoFanerozóico. Dissertação (Mestrado). Instituto de Geociências, Universidade de São Paulo, São Paulo.

Hoffman, P.F., Kaufman, A.J., Halverson, G.P., Schrag, D.P.A., 1998. Neoproterozoic Snowball Earth. Science 281, 1342-1346.
Jones, J.P., 1985. The southern border of the Guaporé shield in Western Brazil and Bolivia: an interpretation of its geologic evolution. Precambrian Res. 28, 111-135.

Kennedy, M., Droser, M., Mayer, L.M., Pevear, D., Mrofka, D., 2006. The precambrian oxygenation; inception of the clay mineral factory. Science 311, 1446-1449. https:// doi.org/10.1126/science.1118929.

Kerber, B.B., Rosa, A.L.Z., Gabas, S.G., Leme, J.M., Pacheco, M.L.A.F., 2013. O registro fossilífero de metazoários ediacaranos na América do Sul e suas implicações nos estudos sobre origem e complexificação da vida animal. Geol. Usp. Série Científica 13 (3), 51-64. https://doi.org/10.5327/Z1519-874X201300030006.

Li, Z., Evans, D.A.D., Halverson, G.P., 2003. Neoproterozoic glaciations in a revised global palaeogeography from the breakup of Rodinia to the assembly of Gondwanaland. Sediment. Geol. 294https://doi.org/10.1016/j.sedgeo.2013.05.016. 219-323.

Lyu, P.-L., Li, W.-X., Wang, X.-C., Pang, C.-J., Cheng, J.-X., Li, X.-H., 2017. Initial breakup of supercontinent Rodinia as recorded by ca 860-840 Ma bimodal volcanism along the southeastern margin of the Yangtze Block, South China. Precambrian Res. 296, 148-167. https://doi.org/10.1016/j.precamres. 2017.04.039.

Meira, F.V.E., 2011. Caracterização tafonômica e estratigráfica de Cloudina lucianoi (Beurlen e Sommer, 1957) Zaine e Fairchild, 1985, no Grupo Corumbá, Ediacarano do Brasil. Dissertação (Mestrado). Instituto de Geociências, Universidade de São Paulo, São Paulo.

Nieto, F., Mata, M.P., Bauluz, B., Giorgetti, G., Arkai, P., Peacor, D.R., 2005. Retrograde diagenesis, a widespread processo $n$ a regional scale. Clay Miner. 40, 93-104. https:// doi.org/10.1180/0009855054010158.

Och, L.M., Shields-Zhou, G.A., 2012. The Neoproterozoic oxygenaton event: environmental perturbations and biogeochemical cycling. Earth Sci. Rev. 110, 26-57. https://doi.org/10.1016/j.earscirev.2011.09.004.

Oliveira, R.S., 2010. Depósitos de rampa carbonática Ediacarana do Grupo Corumbá, região de Corumbá, Mato Grosso do Sul. Dissertação (Mestrado). Instituto de Geociências, Universidade Federal do Pará, Belém.

Parry, L., Boggiani, P.C., Condon, D., Garwood, R., Leme, J.M., Mcllroy, D., Brasier, M.D., Trindade, R., Campanha, G.A.C., Pacheco, M.L.A.F., Diniz, C., Q. C, Lui, A.G., 2017. Ichnological evidence for meiofaunal bilaterians from the terminal Ediacaran and earliest Cambrian of Brazil. Nature Ecology \& Evolution 1, 1455-1464. https://doi. org/10.1038/s41559-017-0301-9.

Piacentini, T., Vasconcelos, P.M., Farley, K.A., 2013. ${ }^{40} \mathrm{Ar} /{ }^{39} \mathrm{Ar}$ constraints on the age and thermal history of the Urucum Neoproterozoic banded iron-formation. Brazil. Precambrian Research 228, 48-62. https://doi.org/10.1016/j.precamres.2013.01. 002.

Sial, A.N., Gaucher, C., Misi, A., Boggiani, P.C., Alvarenga, C.J.S., Ferreira, V.P., Pimentel, M.M., Pedreira, J.A., Warren, L.V., Fernández-Ramírez, R., Geraldes, M., Pereira, N.S., Chiglino, L., Cezario, W.S., 2016. Correlations of some Neoproterozoic carbonate-dominated successions in South America based on high-resolution chemostratigraphy. Braz. J. Genet. 46 (3), 439-488. https://doi.org/10.1590/23174889201620160079.

Spangenberg, J.E., Bagnoud-Velásquez, M., Boggiani, P.C., Gaucher, C., 2014. Redox variations and bioproductivity in the Ediacaran: evidence from inorganic and organic geochemistry of the Corumbá Group, Brazil. Gondwana Res. 26 (3-4), 1186-1207. https://doi.org/10.1016/j.gr.2013.08.014.

Tobias, T.C., 2014. Micropaleontologia da Formação Tamengo, Eco Parque Cacimba da Saúde, Ediacarano, Grupo Corumbá, Estado de Mato Grosso do Sul, Brasil. 88p. Dissertação (Mestrado). Instituto de Geociências, Universidade de Brasília, Brasília.

Trompette, R., Alvarenga, C.J.S., Walde, D., 1998. Geological evolution of the Neoproterozoic Corumbá graben system (Brazil). Depositional context of the stratified Fe and Mn ores of the Jacadigo Group. J. S. Am. Earth Sci. 11 (6), 587-597.

Walde, D.H.G., 1988. Das Proterozoische Paraguay-Araguaia orogen in West-Brasilien, ausgehend von Untersuchungen im Raum Corumbá. Habil. Schrift. Albert-LudwigsUniversitat, Freiburg, pp. 122p.

Walde, D.H.G., Leonardos, O.H., Hahn, G., Hahn, R., Pflug, D.H., 1982. The first Precambrian megafossil from South America: corumbella werneri. An. Acad. Bras. Cienc. 54 (2), 461-485.

Walde, D.H.G., Do Carmo, D.A., Guimarães, E.M., Vieira, L.C., Erdtmann, B.-D., Sanchez, E.A.M., Adorno, R.R., Tobias, T.C., 2015. The Neoproterozoic-Cambrian transition in the Corumbá region. Ann. Palaontol. 101, 213-224. https://doi.org/10.1016/j. annpal.2015.07.002.

Whitney, D.L., Evans, B.W., 2010. Abbreviations for names of rock-forming minerals. Am. Mineral. 95, 185-187. https://doi.org/10.2138/am.2010.3371.

Xiao, S., Narbonne, G.M., Zhou, C., Laflamme, M., Grazhdankin, D.V., MoczydlowskaVidal, M., Cui, H., 2016. Towards an ediacaran time scale: problems, protocols, and prospects. Episodes 39 (4), 540-555. https://doi.org/10.18814/epiiugs/2016/ v39i4/103886.

Zaine, M., 1991. Análise dos fósseis de parte da Faixa Paraguai (MS, MT) e seu contexto temporal e paleoambiental. Ph.D. Thesis. Universidade de São Paulo, Brasil.

Zaine, M.F., Fairchild, T.R., 1985. Comparison of Aulophycus lucianoi Beurlen \& Sommer from Ladário (MS) and the genus Cloudina Germs, ediacaran of Namibia. An. Acad. Bras. Ciências. 57, 130.

Zaine, M.F., Fairchild, T.R., 1987. Novas considerações sobre os fósseis da Formação Tamengo, Grupo Corumbá, SW do Brasil. In: Congresso Brasileiro de Paleontologia. Anais. Rio de Janeiro, pp. 19-25 (de Julho). 